$$
\begin{aligned}
& 984 s \\
& S 439 \\
& S \\
& \text { UC - NRLF }
\end{aligned}
$$

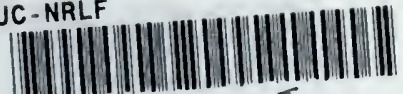

$$
\begin{aligned}
& B \text { ᄅ } 758 \text { 665 }
\end{aligned}
$$



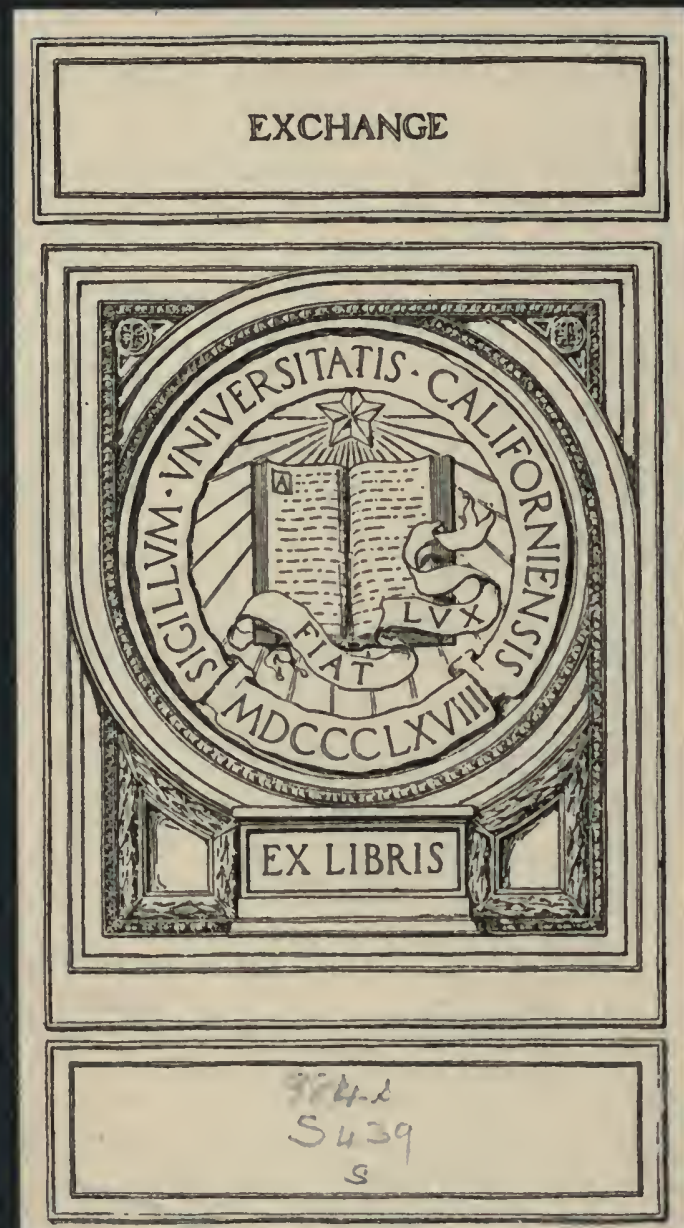


\section{Studies in the Nitrogen Metabolism of Bacteria}

\section{A THESIS}

Submitted to the Department of Chemistry and the Committee on Graduate Study of the Leland Stanford Junior University in partial fulfilment of the requirements for

the degree of Doctor of Philosophy

\section{By}

H. J. SEARS

Stanford University, January, 1916

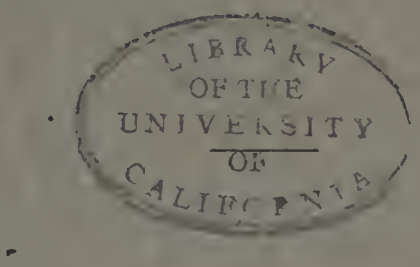

CHICAGO

AMerican Medical Association

Five IIUndred and Tulrty-Five Norti Dearborn Street 



\title{
Studies in the Nitrogen Metabolism of Bacteria
}

\author{
A THESIS \\ Submitted to the Department of Chemistry and the Committee on \\ Graduate Study of the Leland Stanford Junior University \\ in partial fulfilment of the requirements for \\ the degree of Doctor of Philosophy
}

By

H. J. SEARS

Stanford University, January, 1916 
Digitized by the Internet Archive in 2008 with funding from Microsoft Corporation 


\title{
STUDIES IN THE NITROGEN METABOLISM OF BACTERIA*
}

\author{
H. J. SEARS
}

From the Department of Bacteriology and Immunology of Stanford University, California

A chemical study of the metabolism of any organism is generally understood to mean a study of the food materials, the changes which take place in these materials within the organism, the agencies which bring about these changes, and the character and composition of the excretory products. It is obvious that the food materials of microorganisms may be as completely studied as those of higher forms. To determine the changes these undergo within the cell, however, and the exact composition of the excretory products is a problem of a much more difficult nature than the same task would be in the case of the higher plant and animal species.

At present, students of bacterial metabolism must content themselves solely with the study of the beginning and the end of the process. What takes place within the cell can only be surmised from the nature of the enzymes which have been expressed from the bacterial bodies and from the composition of the products of bacterial action. Furthermore, it must be recognized that the substances found in a bacterial culture medium after a period of growth need not all necessarily represent the end products of metabolism. There are numerous possibilities for alteration of the true metabolic products by means of their mutual action upon one another.

In the knowledge of these difficulties, therefore, we shall have to interpret the title of this paper to mean merely a study of the nitrogenous constituents of the food supply of bacteria and a chemical examination of the products of the action of bacteria upon these food substances.

There has been no attempt on the part of investigators to make a complete study of the metabolism of any micro-organism. In fact, such a study would, in most cases, include so wide a variety of food materials and metabolic end products that the large amount of work involved would hardly be in keeping with the benefit to be gained from 


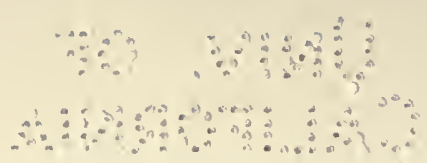

it. Knowledge of the subject has been obtained, therefore, largely by indirect routes, through researches undertaken with some other object in view.

The phenomenon of putrefaction has long been a subject for chemical research, the impetus to its investigation being derived partly from its relation to processes taking place in the intestinal tract of man and animals and partly from its relation to the preservation of food-stuffs. Earlier experiments were all of a general nature, however, being carried out either on spontaneously putrefying masses or on pure proteins inoculated from such masses. The only results were the recognition of a number of compounds as characteristic putrefactive products, and the isolation of many toxic substances. Much benefit was derived from these investigations by the subjects of medicine and biological chemistry, but little was added by them to the knowledge of bacterial metabolism. More productive in this direction has been some of the work of later years, in much of which both pure proteins and pure cultures of bacteria have been used.

The search for new and better culture media, or for media adapted to the growth of certain species of micro-organisms, has been responsible for many valuable contributions, particularly to the knowledge of what sort of nitrogenous compounds can be utilized by bacteria. Likewise, attempts to differentiate species by taking advantage of the dissimilarities in their nitrogen requirements and by noting the different products resulting from the decomposition of the same nitrogenous substance by different species, have led to a more careful investigation of nitrogen sources and of the end products of nitrogen metabolism. It is to these attempts that we owe the extensive data to be obtained on the subject of indol-formation by bacteria, as well as on their reducing and fermenting powers. In recent years the subject of creatininformation has been studied with the same object in view.

It is not likely that it is possible for any organism to grow and reproduce without any source of nitrogen in its food supply, tho Fermi ${ }^{1}$ asserted that he had cultivated a micro-organism containing no nitrogen in its body substance. In the form, however, in which this nitrogen may be offered there is extremely wide variation. As has been known since the work of Berthelot ${ }^{2}$ in 1899, there are many species which thrive with no other source of nitrogen than the uncombined atmospheric nitrogen. On the other hand, there are species which will accept such compounds as the chitin ${ }^{3}$ of plant and animal origin, as their only source of this element.

And not only do we notice this variation in the sources of nitrogen among a large number of species, but evell with one and the same species it is now well known that compounds of very different degrees of complexity may be utilized. The same organism may grow with a native protein, a peptone, amino-acids, amides such as urea, or even with ammonium salts, as its only source of nitrogen. Even B. tuberculosis, an organism formerly supposed to be exacting in its cultural requirements, has recently been grown successfully on a medium containing nitrogen only in the form of ammonium compounds."

If bacteria show great variations in their choice of food materials, so also do they show wide differences in the ways in which they alter these materials

1 Schmidt and Weis: Die Bacterien, 1902, p. 102.

2 Chimie vegetale et agricole, $1899,1$.

- Benecke: Botan. Ztg., 1905, 63, p. 227.

- Wherry: Jour. Infect. Dis., 1913, 13, p. 144. Kendall, Day, and Walker: Ibid., 1914, 15 , p. +17 . 
in the course of metabolism, and in the kinds of chemical products which they yield by means of such alteration. Two factors must always be considered in studying the chemical products of bacterial action; namely, the species of the organism and the nature of the substance being acted upon. Upon the same substrate different species may yield very different products; likewise, as would be expected from a unicellular organism, the same species may yield quite diffcrent products when grown on media of different chemical compositions. The actual chemical processes involved in the decomposition of nitrogenous compounds by bacteria are difficult to study. Equations which have been written to represent such decompositions must, for the most part, be placed in the class of speculations. Such speculations are of great value, however, and, no doubt, frequently arrive very close to the truth.

That proteolysis through the agency of bacteria capable of attacking native proteins pursues the same general course as that brought about by the digestive enzymes of the alimentary tract of animals seems to have been established beyond dispute. Emmerling and Rieser ${ }^{8}$ showed that B. fluorescens-liquefaciens digested gelatin with the formation of proteoses and peptones. These were later broken down to lower compounds yielding in the course of a month $25 \%$ of their nitrogen in the form of ammonia. Substitution compounds of ammonia were also found in the form of methylamin, trimethylamin, betain, and cholin. That amino-acids were an intermediary product, however, was evidenced by the fact that they were able to identify arginin and leucin. Cultures of the same organism on fibrin solutions contained tyrosin, leucin, arginin, and aspartic acid. Emmerling ${ }^{B}$ identified the amino-acids, tyrosin and leucin, in cultures of virulent streptococci on blood fibrin. Mono- and trimethylamins were present here also, as well as pyridin bases. According to Taylor, ${ }^{?} \mathrm{~B}$. coli digests pure casein mainly to proteoses and peptones, no appreciable quantities of animo-acid being formed. On the egg-meat mixture employed by Rettger this organism produced profound changes, giving rise to the aromatic compounds indol and skatol, the amino-acids tyrosin, leucin, and tryptophan being identified as intermediary products. Proteoses and peptones were formed also.

In the decomposition of proteins the obligate anaerobes play a most important part. In fact, according to Rettger, ${ }^{\circ}$ true putrefactive changes with the production of the foul-smelling mercaptans and hydrogen sulfid are brought about only by this class of organisms, the part played by the aerobes and facultative anaerobes being that of creating an oxygen-free environment and removing the waste products of the strict anaerobes. From his researches it appears that B. putrificus, B. oedematis, and the bacillus of symptomatic anthrax are the most powerful putrefying organisms among the commoner anaerobes. $\mathrm{B}$. tetanus and $\mathrm{B}$. welchii have little or no putrefactive power, the latter being primarily a fermenting organism.

The decomposition of the primary products of protein hydrolysis by bacteria has been studied but little, altho mixtures of peptones and proteoses sold as peptone have long been the favorite basic substance in bacterial culture media. By means of the change in the rotation of polarized light, Abderhalden. Pincussohn, and Walther ${ }^{10}$ studied a number of the common pathogens with

s Ber. d. deutsch. chem. Gesellsch., 1902, 35, p. 702.

- Ibid., 1897, 30, p. 1863.

Z Ztschr. f. physiol. Chem., 1902, 36, p. 487.

8 Am. Jour. Physiol., 1903, 8, p. 284.

- Rettger and Newall: Jour. Biol. Chem., 1912, 13, p. 341. Rettger: Ibid,, 1906, 2, p. 71; 1908,4 , p. 45.

10 Zitschr. f. physiol. Chem., 1910, 68, p. 471. 
respect to the extent to which they break down peptones prepared from pure proteins, and compared the results with the effect on the proteins themselves. Kendall and his co-workers ${ }^{11-17}$ recently studied the production of ammonia by a large number of species, using in some cases Witte's peptone and in others a pep-

- tone solution containing meat juice. Their aim was mainly to investigate the effect that carbohydrates have on the decomposition of the nitrogenous substances. They took the ammonia-production as a measure of proteolysis. Their data show interesting exceptions to the general rule that carbohydrates have a protein-sparing effect.

The investigation by Glenn ${ }^{18}$ of the inhibition of indol-formation by members of the proteus group grown in a peptone-carbohydrate solution also indicates that these compounds materially lessen proteolysis. The author attributes this effect, however, to the inactivation of the tryptic enzymes of the bacteria by the acid products of sugar-fermentation. The decreased gelatin-liquefaction by this group in the presence of sugars fermentable by them he explains in the same way.

Berghaus $^{19}$ also published extensive data on the subject of ammonia-formation by bacteria. He furthermore drew curves representing the production of this compound after chemical inhibition of growth.

Kendall and Farmer ${ }^{11}$ attempted also to measure the rate of the production of amino-acid, but were unable with the method used (formol titration) to get results of any value.

Kendall and Walker ${ }^{15}$ claimed the production of minute quantities of urea from meat-juice peptone solutions, and further stated that the amounts formed day by day were about proportional to the ammonia produced.

Antonoff, ${ }^{20}$ using Weyl's test, and Germàn, ${ }^{21}$ using Salkowski's method, claimed creatinin-production from Witte's peptone for a large number of species. Both investigators believed the tests to have differentiating value. Fitzgerald and Schmidt ${ }^{22}$ repeated these tests, but could find appreciable amounts of creatinin only in cultures of B. proteus. They employed both Weyl's method and Jaffé's picric-acid test.

That polypeptids are produced by bacteria has not been established as far as I know. That they may be utilized, however, as a source of nitrogen is known. Sasaki ${ }^{23}$ demonstrated the ability of a variety of species to split some of the simpler peptids into their constituent amino-acids.

A study of the metabolism of bacteria grown on media containing nitrogen only in the form of amino-acids has been productive of much information that is interesting and valuable. We may deal here with synthetic as well as analytic products. That proteins are synthesized from amino-acids by micro-organisms

11 Kendall and Farmer: Jour. Biol. Chem., 1912, 12, pp. 13, 19, 21, 465, 469.

12 Kendall, Farmer, Bagg, and Day: Ibid., p. 219.

1s Kendall and Farmer: Ibid., 1912, 13, p. 64.

16 Kendall, Day, and Walker: Jour. Infect. Dis., 1913, 13, p. 425.

15 Kendall and Walker: Jour. Biol. Chem., 1913, 15, p. 277.

10 Kendall, Day, and Walker: Jour. Med. Research, 1913, 28, p. 465.

17 Kendall, Day; and WValker: Jour. Am. Chem. Soc., 1913, 35, pp. 1201, 1208, 1211, $1217,1225,1237$.

is Centralbl. f. Bakteriol., I, O., 1911, 58, p. 481.

18 Arch. f. Hyg., 1908, 64, p. 1.

20 Centralbl. f. Bakteriol., I, O., 1906, 43, p. 209.

21 Ibid., 1912, 63, p. 545.

22 Proc. Soc. Exper. Biol. and Med., 1912, 10, p. 55.

23 Biochem. Zischr., 1912, 41, p. 174; 1913, 47, pp. 462. 472. 


\section{Nitrogen Metabolism of Bacteria}

follows as a matter of course when we say that growth is supported by them. That proteins other than those of the bacterial bodies are formed seems to be true also. Moreover, it has been shown by Fränkel ${ }^{23}$ and others ${ }^{28}$ that the characteristic toxins of diphtheria and tetanus are formed in media containing only amino-acids as a source of nitrogen.

The fraction of the nitrogen of the amino-acid that is used in synthesis is always very small. The greater portion is found in the form of simpler compounds. Frouin and Ledebt ${ }^{27}$ grew several species on the amino-acids resulting from the hydrolysis of serum proteins and observed that in all cases a primary acidity was produced which was followed later by strong alkalinity. Rivas ${ }^{23}$ found that a short digestion of peptone with trypsin made it a much better culture medium than the undigested peptone. On such a medium he obtained indol reactions in from 5 to 6 hours.

Of the amino-acids which have been used alone as a source of nitrogen for micro-organisms, asparagin has been most studied. A very large number of organisms are capable of utilizing this compound. The main manner of decomposition is deaminization with formation of aspartic acid and a subsequent production of ammonia from the latter. That nitrogenous products other than ammonia are usually formed also is probable. Nawiasky ${ }^{20}$ made a rather exhaustive study of the action of $\mathrm{B}$. proteus on asparagin when large quantities of the organisms are added to pure asparagin solutions. The most of the nitrogen was recovered in the form of ammonia. About $5 \%$ of the asparagin which disappeared was not accounted for by the ammonia recovered.

Tyrosin is broken down by B. coli and yields $78.7 \%$ of the theoretical amount of p-oxyphenylethylamin. ${ }^{30}$ Traetla Mosca ${ }^{\text {an }}$ found another organism which decomposed this acid with the formation of p-hydrocoumaric acid and ammonia.

Of the nitrogenous compounds other than amino-acids, special interest attaches to those found in more or less abundance in the urine of man and animals. That urea, uric acid, and hippuric acid are attacked by a number of species of bacteria has long been known. Kossiwicz ${ }^{33}$ showed that a number of molds were capable of utilizing these substances also. Liebert ${ }^{33}$ found several varieties of bacteria that decompose uric acid to ammonia, and he stated that allantoin and urea were intermediary products. Certain other organisms have been isolated ${ }^{34}$ which yield only urea from uric acid, no ammonia being formed.

That a very large number of species exist capable of converting urea to ammonium carbonate is evident from the researches of Miquel. ${ }^{25}$ It is probable also that many of the common laboratory forms show this property.

21 Muller: Pflüger's Arch., 1906, 112, p. 245.

23 Hyg. Rundschau, 1894, 4, p. 769.

28 Uschinsky: Centralbl. f. Bakteriol., 1893, 14, p. 316 . Arch. de mèd. expèr. et d'anat. path., 1893, 5, p. 293.

27 Compt. rend. Soc. de biol., 1911, 70, p. 24.

28 Centralbl. f. Bakleriol., I, O., 1912, 63, p. 547.

29 Arch. f. Hyg., 1908, 66, p. 209.

20 Sasaki: Biochem. Ztschr., 1914, 59, p. 429.

si Gazz. chim. Ital., 1910, 40, p. 86.

${ }^{32}$ Ztschr. Gahrungsphysiol., I, 60, and II, 51.

as Botan. Centralbl., 1910, 114, p. 361.

s4 Ulpiani: Jahrb. f. Tierchem., 1903, 33, p. 1034. Gerard: Compt. rend., 1896, 122, p. $1019 ; 123$, p. 185.

s5 Lafar's Handbuch der technischen Mykologie, 1904-1906, 3, p. 71. 
Creatinin is attacked slowly by bacteria ${ }^{88}$ as is creatin also. Nawiasky showed that the latter was decomposed by B. proteus only to the extent of $8.64 \%$. Only $3.69 \%$ of the amount attacked was accounted for by the ammonia produced. He assumed that methylguanidin was formed.

\section{THE PRODUCTION BY BACTERIA OF AMINO-ACID AND AMMONIA} FROM PEPTONE

That ammonia is the chief end product of the nitrogen metabolism of bacteria seems to have been well established. That the ammoniaproduction by an organism growing on a protein or peptone medium is always a measure of the organism's proteolytic activity cannot, from this fact, be assumed to be true. It is quite conceivable that, because of the differences in the rate of the decomposition of the primary products of proteolysis, this criterion might lead us astray. We might. for instance, have an accumulation of amino-acids in the medium and a very slight production of ammonia, or, on the other hand, a decomposition of the amino-acids as fast as formed with a consequently high concentration of ammonia. It would give a better idea, therefore, of the rate and extent of protein-decomposition if data were secured on the concentrations of both amino-acid and ammonia. The new method originated by Van Slyke ${ }^{37}$ for determining amino-acid nitrogen now makes the procuring of such data possible. The analytical results of the examination of a large number of cultures with respect to their change day by day in amino-acid and ammonia content are given in the following pages by means of tables. Some are shown also in the form of curves.

The free ammonia was determined by Folin's aeration method, in which $\mathrm{Ca}(\mathrm{OH})_{2}$ is used to set the ammonia free from its salts. After the ammonia had been completely removed, the sample was filtered off from the excess calcium hydroxid and a determination of the amino-acid was made by Van Slyke's micro method. The Kjeldahl-Gunning-Arnold method was used for total-nitrogen determinations.

The first organisms investigated were the strongly putrefactive facultative anaerobes, B. proteus-vulgaris and B. pyocyaneus. The medium used was a solution containing $2 \%$ peptone and $0.5 \% \mathrm{NaCl}$. Five hundred cubic centimeters of this solution were placed in each of two 1000-c.c. flasks. After sterilization in the autoclave at 15 pounds' extra pressure, they were inoculated and placed in an incubator at $37 \mathrm{C}$. By means of a sterile pipet a sample was withdrawn from each immediately after inoculation, and at intervals of 24 hours thereafter for 11 days. These samples were analysed at once for free ammonia and amino-acids. Creatinin was also determined in the samples from the

30 Ackermann: Ztschr. Biol., 1913, 62, p. 208; 63, p. 78.

${ }^{87}$ Jour. Biol. Chem., 1913, 16, p. 161. 
culture of B. proteus. Tests for this compound in the cultures of B. pyocyaneus were all negative. Folin's ${ }^{23}$ method was employed for the determination of creatinin.

Table 1 gives the analytical data for this test. The figures represent the total amount in milligrams of the substance mentioned at the head of the column, that is present in 100 c.c. of the culture fluid on the corresponding day. The third column under each organism gives the ratio between the amounts of amino-acid nitrogen and ammonia nitrogen present on each day of the test. Chart 1 represents the same results in the form of curves.

The data show very marked differences between the two organisms in their action on peptone solutions. In the culture of B. proteus we notice for the first 2 days a decrease in the amino-acid already present in the medium, followed by a rise in concentration on the 3 rd, 4th and 5th days. Thereafter the concentration rises and falls without any tendency to get very far from a mean value of about 50 $\mathrm{mgm}$. per 100 c.c. The ammonia nitrogen also decreases for the first 2 days, but thereafter rises rapidly until the end of the experiment, reaching the concentration of nearly $70 \mathrm{mgm}$. per 100 c.c. The ratio between the two forms of nitrogen decreases rapidly throughout the test.

The culture of $\mathrm{B}$. pyocyaneus likewise shows an initial decrease in its amino-acid nitrogen, followed by fluctuations up and down until the 6th day, after which there occurs a gradual rise in concentration until the end of the experiment on the 10th day. The free ammonia also suffers a decrease in this culture in the first 24 hours. Thereafter there is a general tendency toward a slow increase of this substance, but in two instances, on the 4 th and 7 th days, a decrease occurs. The ratio, amino-acid nitrogen to ammonia nitrogen, falls in this case also, but the decline is much slower than in the case of $\mathrm{B}$. proteus, and the ratio does not, in the time of the experiment, reach nearly so low a value. These differences are made plainer by the curves. The aminoacid curve of $\mathrm{B}$. pyocyaneus tends to rise rapidly. The free ammonia curve of $B$. proteus rises very rapidly; that of $B$. pyocyaneus is much more gradual.

It is interesting to note that both cultures show an initial decrease in both their amino-acid nitrogen and their ammonia nitrogen, indicating that, for purposes of growth and reproduction, these organisms select the simpler forms of nitrogen in preference to the more complex peptone and proteose molecules. This seems to be in accord with the

3 Jour. Biol. Chem., 1914, 17, p. 469. 


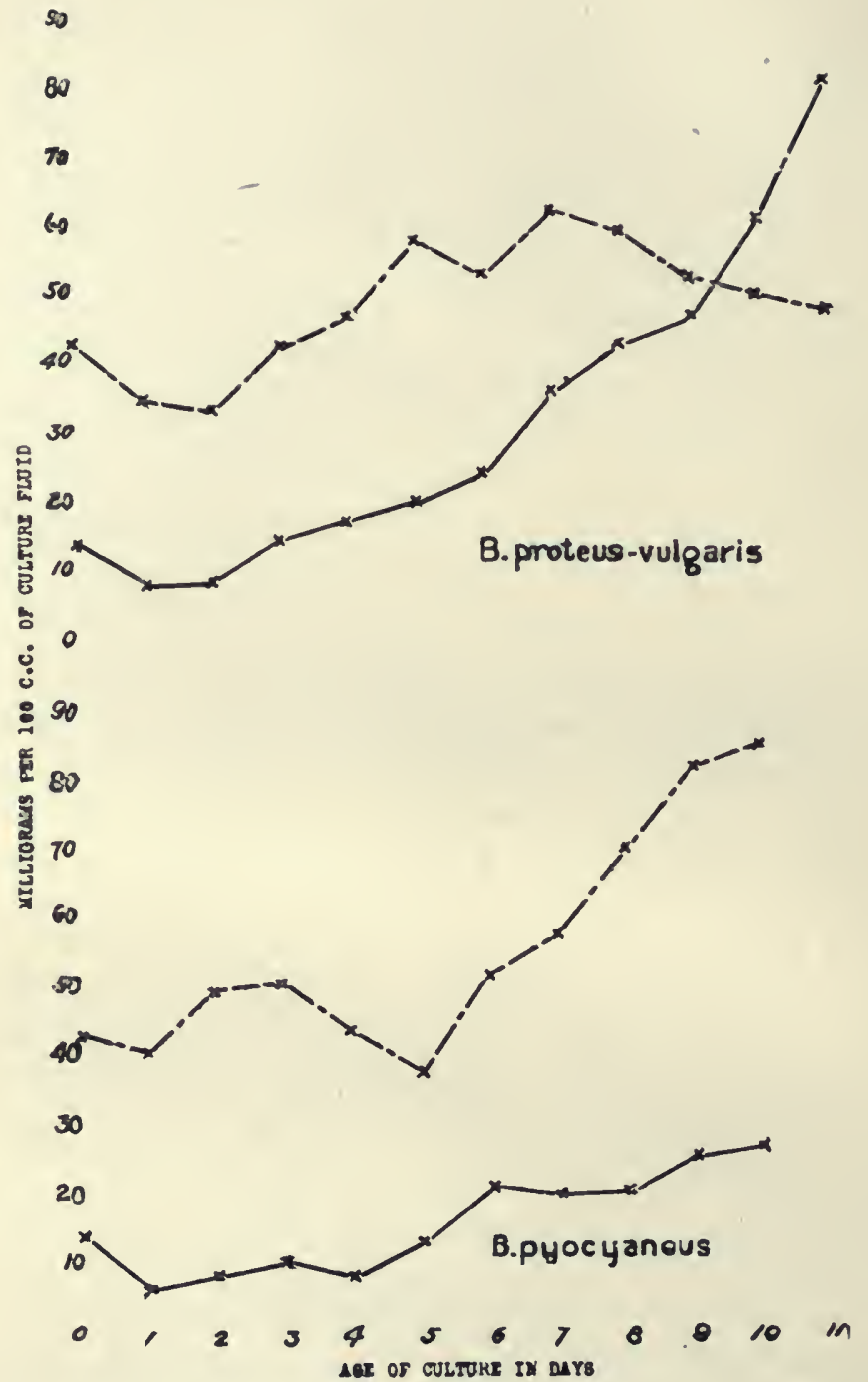

Chart 1. Production of amino-acid and ammonia by bacteria in a $2 \%$ peptone solution - = ammonia nitrogen; $---=$ amino-acid nitrogen. 
finding of Sperry and Rettger ${ }^{39}$ that pure proteins are not attacked by micro-organisms in the entire absence of simpler nitrogenous compounds.

Simultaneously with the foregoing experiment another was made using the same two organisms and also B. coli-communis, but employing a peptone solution containing meat juice instead of the pure peptone media. The medium contained in 1 liter the juice from $1 \mathrm{lb}$. of finely ground lean beef, $10 \mathrm{gm}$. of Witte's peptone, and $5 \mathrm{gm}$. of sodium chlorid. The reaction was made neutral to phenolphthalein. The technic of the experiment was exactly similar to that described. Table 2 and Chart 2 give the analytical results of the test. As in Table 1 the values are given in milligrams per 100 c.c. of the culture fluid.

TABLE 1

The Production of Amino-acid and Ammonia by Bacteria in a $2 \%$ Peptone Solution

\begin{tabular}{|c|c|c|c|c|c|c|c|}
\hline \multirow[b]{2}{*}{$\begin{array}{l}\text { Age of } \\
\text { Culture } \\
\text { in Days }\end{array}$} & \multicolumn{4}{|c|}{ B. Proteus-Vulgaris } & \multicolumn{3}{|c|}{ B. Pyocyaneus } \\
\hline & $\begin{array}{l}\text { Amino- } \\
\text { acid } \\
\text { Nitro- } \\
\text { gen }\end{array}$ & $\begin{array}{c}\text { Am- } \\
\text { monia } \\
\text { Nitro- } \\
\text { gen }\end{array}$ & $\begin{array}{l}\text { Ratio: } \\
\text { Amino- } \\
\text { acid N } \\
\text { Am- }\end{array}$ & $\begin{array}{c}\text { Creat- } \\
\text { inin }\end{array}$ & $\begin{array}{l}\text { Amino- } \\
\text { acid } \\
\text { Nitro- } \\
\text { gen }\end{array}$ & $\begin{array}{c}\text { Am- } \\
\text { monia } \\
\text { Nitro- } \\
\text { gen }\end{array}$ & $\begin{array}{l}\text { Ratio: } \\
\text { Amino- } \\
\text { acid N } \\
\text { Am- }\end{array}$ \\
\hline $\begin{array}{r}0 \\
1 \\
2 \\
3 \\
4 \\
5 \\
6 \\
7 \\
8 \\
9 \\
10 \\
11\end{array}$ & $\begin{array}{l}42.0 \\
34.0 \\
32.9 \\
41.8 \\
45.3 \\
56.5 \\
51.2 \\
60.8 \\
57.9 \\
51.2 \\
48.9 \\
46.2\end{array}$ & $\begin{array}{r}13.3 \\
7.3 \\
7.3 \\
13.0 \\
15.6 \\
18.2 \\
22.7 \\
34.6 \\
41.4 \\
45.3 \\
59.6 \\
69.2\end{array}$ & $\begin{array}{l}4.65 \\
4.52 \\
4.52 \\
3.22 \\
2.91 \\
3.10 \\
2.26 \\
1.76 \\
1.40 \\
1.13 \\
0.82 \\
0.67\end{array}$ & $\begin{array}{c}\bar{z} \\
\bar{z} \\
\overline{-} \\
\text { Trace } \\
\text { Trace } \\
\text { Trace } \\
\text { Trace } \\
\text { Trace } \\
\text { Trace }\end{array}$ & $\begin{array}{l}42.0 \\
39.9 \\
48.2 \\
49.2 \\
42.7 \\
36.6 \\
50.5 \\
56.1 \\
68.8 \\
80.6 \\
83.7 \\
\ldots . .\end{array}$ & $\begin{array}{r}13.3 \\
5.7 \\
7.3 \\
9.2 \\
7.3 \\
12.2 \\
20.0 \\
19.0 \\
19.5 \\
24.7 \\
26.0 \\
\ldots . .\end{array}$ & $\begin{array}{l}7.00 \\
6.62 \\
5.35 \\
5.86 \\
3.00 \\
2.53 \\
2.95 \\
3.54 \\
3.26 \\
3.22 \\
\ldots . .\end{array}$ \\
\hline
\end{tabular}

The figures represent the amount in milligrams of the substance mentioned at the head of the column, that is present in 100 c.c. on the corresponding day.

The chief differences between the data of Table 2 and those of Table 1 are to be seen in the case of the cultures of $\mathrm{B}$. pyocyaneus. In the presence of the muscle extractives this organism shows a considerably higher production of ammonia and a much lower production of amino-acid. There is no tendency at all toward an accumulation of the latter in the medium. Evidently in the case of this bacillus the constituents of the meat juice have a marked protein-sparing effect. The rapidly decreasing figures for creatinin indicate that this compound, at least, is easily utilized.

39 Jour. Biol. Chem., 1915, 20, p. 445. 


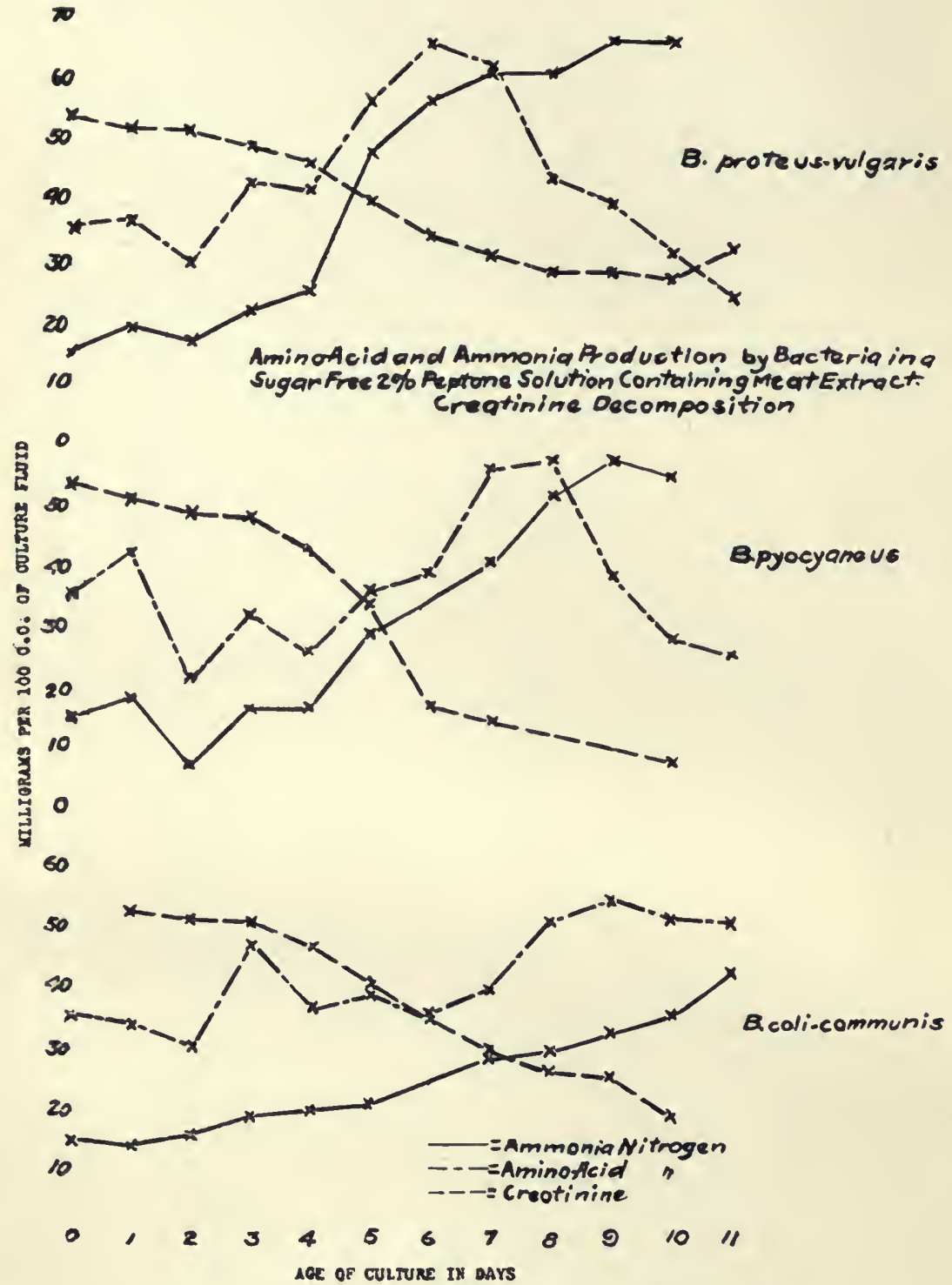

Chart 2. The key to this chart applies also to Charts 3,4 , and 5. 
B. proteus gives very similar curves for ammonia and amino-acid, as it did in the $2 \%$ peptone solution, the ammonia values being high and the amino-acid values comparatively low, but showing, however, a tendency toward a maximum about the 6th day. On account of the ability of this organism to produce creatinin from peptone, the values for this compound cannot be taken to indicate the extent to which the extractives are utilized.

B. coli shows somewhat high ammonia values; in view of the comparative volumes of the cultures, they are enormously higher than the values on corresponding days shown by this organism in pure peptone solutions (see Table 4 ).

TABLE 2

The Production of Amino-acid and Ammonia by Bacteria in Meat-Extract Peptone Solutions

\begin{tabular}{|c|c|c|c|c|c|c|c|c|c|}
\hline \multirow{2}{*}{$\begin{array}{l}\text { Age } \\
\text { of } \\
\text { Cul- } \\
\text { ture } \\
\text { in } \\
\text { Days }\end{array}$} & \multicolumn{3}{|c|}{ B. Proteus } & \multicolumn{3}{|c|}{ B. Pyocy aneus } & \multicolumn{3}{|c|}{ B. Coli } \\
\hline & $\begin{array}{l}\text { Amino- } \\
\text { acid } \\
\text { Nitro- } \\
\text { gen }\end{array}$ & $\begin{array}{l}\text { Am- } \\
\text { monia } \\
\text { Nitro- } \\
\text { gen. }\end{array}$ & $\begin{array}{c}\text { Creat- } \\
\text { inin }\end{array}$ & $\begin{array}{l}\text { Amino- } \\
\text { acid } \\
\text { Nitro- } \\
\text { gen }\end{array}$ & $\begin{array}{c}\text { Am- } \\
\text { monia } \\
\text { Nitro- } \\
\text { gen }\end{array}$ & $\begin{array}{c}\text { Creat- } \\
\text { jnin }\end{array}$ & $\begin{array}{l}\text { Amino- } \\
\text { acid } \\
\text { Nitro- } \\
\text { gen }\end{array}$ & $\begin{array}{l}\text { Am- } \\
\text { monia } \\
\text { Nitro- } \\
\text { gen }\end{array}$ & $\begin{array}{c}\text { Creat. } \\
\text { inin }\end{array}$ \\
\hline $\begin{array}{r}0 \\
1 \\
2 \\
3 \\
4 \\
5 \\
6 \\
7 \\
8 \\
9 \\
10 \\
11\end{array}$ & $\begin{array}{l}35.0 \\
36.1 \\
29.1 \\
42.4 \\
41.6 \\
55.9 \\
65.1 \\
61.7 \\
42.8 \\
38.5 \\
30.1 \\
23.1\end{array}$ & $\begin{array}{l}14.9 \\
18.7 \\
16.2 \\
21.1 \\
24.7 \\
47.4 \\
56.0 \\
60.2 \\
60.2 \\
65.7 \\
65.0 \\
\ldots . .\end{array}$ & $\begin{array}{l}53.1 \\
51.2 \\
51.0 \\
48.5 \\
45.8 \\
39.4 \\
33.8 \\
30.3 \\
27.6 \\
27.6 \\
26.1 \\
31.0\end{array}$ & $\begin{array}{l}35.0 \\
41.8 \\
21.0 \\
31.4 \\
25.3 \\
35.2 \\
38.4 \\
55.1 \\
56.6 \\
37.6 \\
27.2 \\
24.4\end{array}$ & $\begin{array}{r}14.9 \\
17.9 \\
6.8 \\
16.2 \\
16.2 \\
28.4 \\
33.9 \\
39.8 \\
50.8 \\
56.5 \\
53.6 \\
52.1\end{array}$ & $\begin{array}{r}53.1 \\
50.7 \\
48.0 \\
47.8 \\
42.7 \\
33.1 \\
16.2 \\
13.6 \\
11.7 \\
9.2 \\
7.0 \\
6.0\end{array}$ & $\begin{array}{l}35.0 \\
33.6 \\
29.9 \\
46.7 \\
36.0 \\
38.5 \\
35.3 \\
39.5 \\
50.6 \\
54.1 \\
51.2 \\
50.9\end{array}$ & $\begin{array}{l}14.9 \\
13.5 \\
15.6 \\
18.4 \\
19.3 \\
20.6 \\
24.2 \\
28.4 \\
29.6 \\
32.5 \\
35.4 \\
42.2\end{array}$ & $\begin{array}{l}53.1 \\
52.7 \\
51.2 \\
50.6 \\
46.5 \\
40.1 \\
35.0 \\
29.8 \\
26.1 \\
25.2 \\
18.6 \\
16.1\end{array}$ \\
\hline
\end{tabular}

As none of the organisms used in the described tests reached the limits of its chemical activity in the time of the experiment, it was thought worth while to repeat the experiment, continuing it over a longer period. Furthermore, as it was thought possible that the removal of samples with a pipet every 24 hours might introduce errors by disturbing the culture or through failure to take account of slight differences that might exist in the concentration of the substances determined in different layers of the solution, the following rather tedious method was used:

A $2 \%$ peptone solution containing $0.5 \% \mathrm{NaCl}$ was made up and placed in 40-c.c. portions in small Erlenmeyer flasks. These, after sterilization in the autoclave, were all placed in the incubator at $37 \mathrm{C}$. Each day 2 flasks were inoculated with 1 loopful of a 24-hour peptone culture of B. proteus and B. pyocyaneus, respectively. In this way separate cultures, were obtained ranging in age from 1 to 28 days, all of which had been inoculated with approximately 
the same number of organisms and kept for the full time of the experiment under exactly the same conditions. When all but the control flask had been inoculated, they were sterilized by the addition of about $2 \%$ phenol. Two cubic centimeters of $\mathrm{N} / 1 \mathrm{HCl}$ were added to each and the cultures filtered. The filtrate, which was fairly clear, was made up to volume and aliquot parts taken for the determinations. Table 3 gives the analytical results. As in Tables 1 and 2 , the values are given in milligrams per 100 c.c. of the culture medium.

TABLE 3

The Production of Amino-acid and Ammonia by Bacteria in a Peptone Solution

\begin{tabular}{|c|c|c|c|c|c|c|c|c|}
\hline \multirow[b]{2}{*}{$\begin{array}{c}\text { Age of } \\
\text { Culture } \\
\text { in } \\
\text { Days }\end{array}$} & \multicolumn{5}{|c|}{ B. Proteus-Vulgaris } & \multicolumn{3}{|c|}{ B. Pyocyaneus } \\
\hline & $\begin{array}{l}\text { Amino- } \\
\text { acid } \\
\text { Nitro- } \\
\text { gen }\end{array}$ & $\begin{array}{c}\text { Am- } \\
\text { monia } \\
\text { Nitro- } \\
\text { gen }\end{array}$ & $\begin{array}{l}\text { Ratio: } \\
\text { Amino- } \\
\frac{\text { acid N }}{\text { Am- }} \\
\text { monia } \mathbf{N}\end{array}$ & $\underset{\text { inin }}{\text { Creat. }}$ & $\begin{array}{c}\text { Crea. } \\
\text { tin }\end{array}$ & $\begin{array}{l}\text { Amino- } \\
\text { acid } \\
\text { Nitro- } \\
\text { gen }\end{array}$ & $\begin{array}{l}\text { Am- } \\
\text { monia } \\
\text { Nitro- } \\
\text { gen }\end{array}$ & $\begin{array}{l}\text { Ralio: } \\
\text { Amino- } \\
\text { acid } \mathbf{5}\end{array}$ \\
\hline $\begin{array}{r}0 \\
1 \\
2 \\
3 \\
4 \\
5 \\
6 \\
7 \\
8 \\
9 \\
10 \\
11 \\
12 \\
13 \\
14 \\
15 \\
16 \\
17 \\
18 \\
19 \\
20 \\
21 \\
22 \\
23 \\
24 \\
25 \\
26 \\
27 \\
28\end{array}$ & $\begin{array}{l}37.0 \\
62.0 \\
60.0 \\
54.5 \\
60.0 \\
56.5 \\
59.7 \\
43.2 \\
52.5 \\
39.5 \\
39.5 \\
32.5 \\
37.0 \\
27.0 \\
27.5 \\
27.0 \\
31.4 \\
30.0 \\
27.0 \\
20.0 \\
28.8 \\
29.8 \\
25.0 \\
23.7 \\
22.5 \\
27.0 \\
24.5 \\
22.0 \\
22.5\end{array}$ & $\begin{array}{r}6.5 \\
24.2 \\
25.0 \\
40.5 \\
40.5 \\
63.7 \\
59.0 \\
81.2 \\
96.2 \\
92.5 \\
81.5 \\
104.0 \\
103.0 \\
120.0 \\
122.0 \\
124.0 \\
122.0 \\
108.0 \\
127.0 \\
114.0 \\
137.0 \\
86.7 \\
111.0 \\
159.0 \\
136.0 \\
112.0 \\
109.0 \\
97.4 \\
81.0\end{array}$ & $\begin{array}{l}5.70 \\
2.56 \\
2.40 \\
1.34 \\
1.48 \\
1.05 \\
1.01 \\
0.54 \\
0.55 \\
0.43 \\
0.49 \\
0.32 \\
0.35 \\
\ldots . .23 \\
0.22 \\
0.26 \\
0.28 \\
0.21 \\
0.19 \\
0.21 \\
0.35 \\
0.23 \\
0.15 \\
0.16 \\
0.24 \\
0.22 \\
0.23 \\
0.28\end{array}$ & $\begin{array}{c}\ldots . . \\
\text { Trace } \\
\text { Trace } \\
\text { Trace } \\
\text { Trace } \\
\text { Trace } \\
\text { Trace } \\
\text { Trace } \\
6.1 \\
6.0 \\
6.5 \\
6.5 \\
6.5 \\
7.3 \\
6.3 \\
6.0 \\
7.7 \\
7.3 \\
7.3 \\
8.0 \\
7.5 \\
5.5 \\
4.8 \\
6.7 \\
8.2 \\
7.0 \\
7.5 \\
6.0\end{array}$ & $\begin{array}{c}\ldots . \\
\ldots . \\
6.3 \\
10.5 \\
\ldots . . \\
\ldots . \\
11.0 \\
\ldots . \\
\ldots . \\
16.5 \\
\ldots . \\
\ldots . \\
14.4 \\
\ldots . . \\
\ldots . . \\
\ldots . . \\
14.2 \\
\ldots . .5 \\
\ldots .5 \\
\ldots . . \\
4.5\end{array}$ & $\begin{array}{r}37.0 \\
44.4 \\
89.4 \\
112.0 \\
63.1 \\
84.3 \\
80.0 \\
116.0 \\
59.8 \\
120.0 \\
59.2 \\
101.0 \\
53.0 \\
70.5 \\
81.3 \\
93.0 \\
139.0 \\
97.5 \\
102.0 \\
100.0 \\
107.0 \\
104.0 \\
49.0 \\
45.4 \\
60.0 \\
60.0 \\
\ldots . . \\
\ldots 4.0\end{array}$ & $\begin{array}{r}6.5 \\
14.5 \\
21.8 \\
28.1 \\
25.4 \\
28.1 \\
31.8 \\
37.2 \\
39.8 \\
51.0 \\
46.7 \\
65.7 \\
43.8 \\
47.9 \\
69.7 \\
70.0 \\
71.7 \\
49.0 \\
63.5 \\
63.5 \\
60.0 \\
59.0 \\
50.7 \\
39.0 \\
54.5 \\
38.1 \\
65.0 \\
59.7 \\
49.8\end{array}$ & $\begin{array}{l}5.70 \\
3.06 \\
4.10 \\
5.14 \\
2.48 \\
3.00 \\
2.52 \\
3.12 \\
1.50 \\
2.36 \\
1.27 \\
1.54 \\
1.21 \\
1.47 \\
1.17 \\
1.33 \\
1.94 \\
1.99 \\
1.61 \\
1.58 \\
1.78 \\
1.76 \\
0.97 \\
1.15 \\
1.10 \\
1.58 \\
\ldots \ldots \\
\ldots . .2\end{array}$ \\
\hline
\end{tabular}

A number of interesting facts are brought out by this experiment. In the first place, the ammonia figures do not, in either case, indicate the relative ages of the cultures. The 10-day culture of $\mathrm{B}$. proteus, for example, shows a lower concentration of ammonia nitrogen than the 8-day culture. Likewise, the 12-day culture of $\mathrm{B}$. pyocyaneus contains a lower concentration of this compound than the 9-day culture. Many other instances of the same irregularity may be noted. It is apparent, therefore, that different cultures of the same organism on the same media and in exactly equal volumes may show quite different rates of ammonia-formation, even when made and grown under exactly the same conditions. In the case of both organisms, however, there is a general increase of ammonia-formation on the part of the older cultures up to the 15 th or 16th day. After this the values fluctuate without any regular increase. Evidently, in the volume of media used, these organisms reach their maximum of ammonia-production in from about 14 to 18 days. 
The amino-acid figures are comparable with those of Table 1. B. proteus gives a fluctuating, but consistently low value, while $B$. pyocyaneus gives a relatively high value, which shows a tendency to increase with the age of the culture. The ratios, when the volumes concerned are taken into account, show practically the same characteristics as those in Table 1.

An experiment similar to the foregoing was carried out also on the three organisms, B. coli-communis, B. typhosus, and Sp. cholerae. The technic was identical with that described in the case of $\mathrm{B}$. proteus and $\mathrm{B}$. pyocyaneus. Table 4 gives the data on this experiment.

TABLE 4

Tije Prodection of Amino-acid and Ammonia by Bacteria in a Peptone Solution

\begin{tabular}{|c|c|c|c|c|c|c|c|c|c|}
\hline \multirow[b]{2}{*}{$\begin{array}{l}\text { Age } \\
\text { of } \\
\text { Cul- } \\
\text { tures } \\
\text { in } \\
\text { Days }\end{array}$} & \multicolumn{3}{|c|}{ B. Coli-Communis } & \multicolumn{3}{|c|}{ B. Typhosus } & \multicolumn{3}{|c|}{ Sp. Cholerae } \\
\hline & $\begin{array}{l}\text { Amino- } \\
\text { acid } \\
\text { Nitro- } \\
\text { gen }\end{array}$ & $\begin{array}{c}\text { Am- } \\
\text { monia } \\
\text { Nitro- } \\
\text { gen }\end{array}$ & $\begin{array}{l}\begin{array}{c}\text { Ratio: } \\
\text { Amino- } \\
\text { acid N }\end{array} \\
\text { Am- } \\
\text { monia } N\end{array}$ & $\begin{array}{l}\text { Amino- } \\
\text { acid } \\
\text { Nitro- } \\
\text { gen }\end{array}$ & $\begin{array}{l}\text { Am- } \\
\text { monia } \\
\text { Nitro- } \\
\text { gen }\end{array}$ & $\frac{\begin{array}{c}\text { Ratio: } \\
\text { Amino- } \\
\text { aeld } \mathbf{N}\end{array}}{\text { Am- }}$ & $\begin{array}{l}\text { Amino- } \\
\text { aeid } \\
\text { Nitro- } \\
\text { gen }\end{array}$ & $\begin{array}{l}\text { Am- } \\
\text { monia } \\
\text { Nítro- } \\
\text { gen }\end{array}$ & $\mid \begin{array}{l}\text { Ratio: } \\
\text { Amino- } \\
\text { acid N } \\
\text { Am- } \\
\text { monia N }\end{array}$ \\
\hline $\begin{array}{r}0 \\
2 \\
3 \\
4 \\
5 \\
6 \\
8 \\
10 \\
12 \\
15 \\
18 \\
21\end{array}$ & $\begin{array}{l}30.8 \\
27.7 \\
28.6 \\
26.8 \\
35.7 \\
34.4 \\
30.6 \\
37.1 \\
31.1 \\
\dddot{17.8} \\
45.0\end{array}$ & $\begin{array}{r}7.1 \\
11.6 \\
7.7 \\
5.4 \\
9.3 \\
9.7 \\
10.9 \\
13.7 \\
15.4 \\
16.6 \\
16.9 \\
24.2\end{array}$ & $\begin{array}{l}4.34 \\
2.39 \\
3.74 \\
5.01 \\
3.84 \\
3.55 \\
2.90 \\
2.71 \\
2.02 \\
2 . .8 \\
2.83 \\
1.86\end{array}$ & $\begin{array}{l}30.8 \\
39.3 \\
36.2 \\
35.6 \\
32.2 \\
30.4 \\
31.2 \\
34.8 \\
36.6 \\
31.7 \\
31.2 \\
33.9\end{array}$ & $\begin{array}{r}7.1 \\
12.8 \\
9.3 \\
9.8 \\
12.8 \\
10.9 \\
9.9 \\
11.6 \\
9.3 \\
11.6 \\
21.0 \\
13.9\end{array}$ & $\begin{array}{l}4.23 \\
3.07 \\
3.89 \\
3.64 \\
2.52 \\
2.79 \\
3.16 \\
3.00 \\
3.94 \\
2.74 \\
1.49 \\
2.44\end{array}$ & $\begin{array}{c}30.8 \\
37.9 \\
45.7 \\
51.9 \\
65.6 \\
73.2 \\
35.7 \\
97.7 \\
\ldots 17.1 \\
\ldots \ldots \\
\ldots . .\end{array}$ & $\begin{array}{r}7.1 \\
12.5 \\
15.7 \\
22.0 \\
29.2 \\
29.2 \\
21.0 \\
34.7 \\
49.9 \\
52.2 \\
52.0 \\
46.0\end{array}$ & $\begin{array}{c}4.34 \\
3.03 \\
2.91 \\
2.36 \\
2.25 \\
2.51 \\
1.70 \\
2.82 \\
\ldots . .5 \\
2.25 \\
\ldots . .\end{array}$ \\
\hline
\end{tabular}

Little comment is necessary on these figures. The irregularity in the rate of ammonia-production which was mentioned in connection with Table 3 is found here also. It will be observed, however, that the figures representing the concentrations of amino-acid nitrogen deviate very little in the case of B. coli and B. typhosus from those found with uninoculated medium. In the culture of Sp. cholerae there is a decided increase of amino-acid nitrogen with the age of the culture. As would be expected, the ammonia-production by this organism is relatively high also.

With the same technic as that just described, cultures were examined of B. proteus-vulgaris on a $1 \%$ peptone solution containing $10 \mathrm{gm}$. of Liebig's meat extract per liter. In addition to amino-acid nitrogen and ammonia, both creatin and creatinin were determined in this case. Table 5, which gives the analytical data for the test, shows that on this medium also there is a very great irregularity in the production of ammonia. It is impossible to estimate from these data at what age cessation of chemical activity occurs. The creatinin values would indicate that this compound is continuously decomposed throughout the entire period of 37 days. The fluctuating values for creatin are undoubtedly due, in part, to the different degrees to which this substance is decomposed in sterilization.

It is evident from these examples that this method of procedure is unsuited to the quantitative study of the peptolytic activity of microorganisms. Succeeding experiments were carried on, therefore, with 
the technic employed in the original experiments ; namely, that of inoculating a large volume of the medium and withdrawing samples day by day with a sterile pipet. It was further determined also to study the effect of glucose on amino-acid-production. It had been shown clearly by Kendall and his co-workers that this carbohydrate very considerably reduced the rate of ammonia-formation by most micro-organisms. It was a matter of interest to know also whether it would reduce aminoacid-production.

TABLE 5

The Production of Amino-acid and Ammonia by B. Proteus-Vulgaris in a Meat-Extract Peptone Solution

\begin{tabular}{|c|c|c|c|c|c|c|}
\hline $\begin{array}{c}\text { Age of } \\
\text { Culture } \\
\text { in } \\
\text { Days }\end{array}$ & $\begin{array}{l}\text { Amino- } \\
\text { acid } \\
\text { Nitrogen }\end{array}$ & $\underset{\text { Nitrogen }}{\text { Ammonia }}$ & $\begin{array}{c}\text { Ratio: } \\
\text { Amino-aeid } \mathbf{N} \\
\text { Ammonia } \mathbf{N}\end{array}$ & Crentinin & Creatin & $\begin{array}{l}\text { Amino-acid } \mathbf{X} \\
\text { plus } \\
\text { Ammonia } \mathbf{X}\end{array}$ \\
\hline $\begin{array}{r}0 \\
2 \\
4 \\
5 \\
5 \\
y \\
11 \\
13 \\
14 \\
15 \\
18 \\
21 \\
23 \\
26 \\
24 \\
35 \\
37\end{array}$ & $\begin{array}{l}38.8 \\
65.8 \\
70.5 \\
69.5 \\
38.8 \\
30.6 \\
42.5 \\
36.5 \\
36.5 \\
29.8 \\
28.4 \\
41.8 \\
34.6 \\
19.1 \\
28.6 \\
30.1 \\
\ldots . .\end{array}$ & $\begin{array}{l}11.6 \\
15.0 \\
36.2 \\
46.4 \\
50.8 \\
58.0 \\
18.0 \\
55.2 \\
52.0 \\
51.7 \\
26.9 \\
67.7 \\
45.2 \\
28.2 \\
36.2 \\
40.0 \\
47.1\end{array}$ & $\begin{array}{l}3.34 \\
4.35 \\
1.95 \\
1.50 \\
0.76 \\
0.53 \\
0.88 \\
0.66 \\
0.70 \\
0.58 \\
1.05 \\
0.62 \\
0.76 \\
0.68 \\
0.79 \\
0.75 \\
\ldots . .\end{array}$ & $\begin{array}{l}62.0 \\
61.0 \\
57.2 \\
57.0 \\
37.6 \\
34.1 \\
29.4 \\
30.3 \\
39.0 \\
38.1 \\
27.6 \\
30.8 \\
27.8 \\
23.0 \\
19.6 \\
20.5 \\
17.9\end{array}$ & $\begin{array}{l}48.0 \\
43.0 \\
39.8 \\
43.0 \\
47.9 \\
54.6 \\
56.1 \\
44.7 \\
41.0 \\
53.9 \\
54.9 \\
50.7 \\
45.2 \\
53.5 \\
43.3 \\
47.1 \\
51.6\end{array}$ & $\begin{array}{r}50.4 \\
80.8 \\
106.7 \\
115.9 \\
89.6 \\
88.6 \\
90.5 \\
91.7 \\
88.5 \\
81.5 \\
55.3 \\
109.5 \\
79.8 \\
47.3 \\
64.8 \\
70.1 \\
\ldots . .\end{array}$ \\
\hline
\end{tabular}

Seven organisms were investigated in this respect. The exact technic of the experiment was as follows. A large amount of a $2 \%$ peptone solution containing $0.5 \% \mathrm{NaCl}$ was prepared and divided into 2 equal portions, to one of which was added approximately $1 \%$ of pure glucose. The media were then placed in 500-c.c. flasks, 300 c.c. to each. To each of the flasks containing glucose a small amount of $\mathrm{CaCo}_{3}$ was added. All the samples were sterilized together in the autoclave for 10 minutes under an extra pressure of $15 \mathrm{lb}$. They were all inoculated at $37 \mathrm{C}$. in the same incubator. The incubator was kept saturated with moisture to prevent evaporation. Samples, 15 c.c. in amount, were withdrawn at intervals as indicated in the tables, and were subjected at once to a half hour's heating in steam at $100 \mathrm{C}$. This would, of course, not sterilize the cultures of $\mathrm{B}$. subtilis, but as the analyses were usually completed on the same day that the samples were taken (otherwise the samples were kept in the ice chest), it is not probable that any error was introduced by that fact.

Tables 6 to 12 inclusive give the results of the analyses of these samples. Charts 3 to 5 represent the same results in the form of curves. 
An examination of the tables, or a glance at the curves, shows at once that, as would be expected, the peptolytic activity of B. subtilis is much greater than that of any of the rest, Sp. metchnikovii being the only one in this group which shows a comparable production of aminoacid or of ammonia. It is unfortunate that, as the result of a contamination on the 7 th day, the examination of the only other organism having a gelatin-liquefying power, namely, Staphylococcus pyogenes, could not be carried out over the full period. The data obtained, however, indicate that in its chemical activity it is to be compared with the nonliquefying member of the group rather than with those mentioned.

The effect of glucose on the nitrogen metabolism of the cultures is apparent in both the amino-acid and the free-ammonia curves. In all cases, except those of B. faecalis-alkaligenes and B. dysenteriae, there is an unquestionably lower ammonia-production in the cultures containing glucose. The cultures of B. dysenteriae, when the slightly different conditions which may exist in the two flasks are taken into account, may be said to give practically identical ammonia curves. The same is probably true of $\mathrm{B}$. faecalis-alkaligenes, altho it is interesting to note that, in this case, the curve of the glucose-containing culture is consistently above that of the one containing no glucose.

If it is assumed that neither of the organisms just mentioned is capable of utilizing glucose, it becomes difficult to explain the lower concentrations of amino-acids in the cultures containing this carbohydrate. There seem to be but two possible explanations of this fact. Either the glucose shows a protein-sparing action in that it decreases the peptone-decomposition by the organisms, or it acts in a manner that must be considered the direct opposite of this. That is, it brings about a more rapid breaking-down into simpler compounds of nitrogen of the amino-acids resulting from the splitting of the peptone. In this case it is necessary to assume that the breaking down of the amino-acids is not carried on to the free-ammonia stage or else that this stage is passed and free nitrogen or the oxids of nitrogen are formed.

The latter theory is so entirely in disagreement with all the wellknown biologic reactions of glucose that it may safely be put out of consideration at once. If we accept then as an explanation of the facts the theory of decreased nitrogen metabolism, we have two instances of this phenomenon which are not indicated by the production of free ammonia. 
TABLE 6

Tile Formation of Amino-acid and Ammonia from Peptone by B. Paratyphosus Total Nitrogen $=304$ mGM. PER 100 c.c.

\begin{tabular}{|c|c|c|c|c|c|c|}
\hline \multirow[b]{2}{*}{$\begin{array}{l}\text { Age of } \\
\text { Culture } \\
\text { In } \\
\text { Days }\end{array}$} & \multicolumn{3}{|c|}{ Without Glucose } & \multicolumn{3}{|c|}{ With Glucose } \\
\hline & $\begin{array}{l}\text { Amino- } \\
\text { acid } \\
\text { Nitro- } \\
\text { gen }\end{array}$ & $\begin{array}{c}\text { Ammonia } \\
\text { Nitro- } \\
\text { gen }\end{array}$ & $\begin{array}{c}\text { Ratio: } \\
\text { Amino-acid } N \\
\text { Ammonia } N\end{array}$ & $\begin{array}{l}\text { Amino- } \\
\text { acid } \\
\text { Nitro- } \\
\text { gen }\end{array}$ & $\begin{array}{c}\text { Ammonia } \\
\text { Nitro- } \\
\text { gen }\end{array}$ & $\begin{array}{c}\text { Ratio: } \\
\text { Amino-acid } N \\
\text { Ammonia } N\end{array}$ \\
\hline $\begin{array}{r}0 \\
1 \\
2 \\
3 \\
4 \\
5 \\
6 \\
7 \\
9 \\
11 \\
14 \\
18\end{array}$ & $\begin{array}{l}42.4 \\
56.7 \\
42.5 \\
42.0 \\
35.7 \\
\ldots . . \\
36.3 \\
32.0 \\
31.9 \\
33.1 \\
41.0 \\
42.7\end{array}$ & $\begin{array}{l}3.5 \\
4.3 \\
4.4 \\
3.2 \\
4.7 \\
7.8 \\
\ddot{8.1} \\
9.2 \\
9.0 \\
9.9 \\
9.1\end{array}$ & $\begin{array}{r}12.10 \\
13.20 \\
9.67 \\
13.10 \\
7.61 \\
\ldots \ldots \\
\ldots . .9 \\
3.95 \\
3.47 \\
3.67 \\
4.14 \\
4.68\end{array}$ & $\begin{array}{l}42.4 \\
34.1 \\
38.6 \\
28.5 \\
26.2 \\
34.0 \\
29.5 \\
31.2 \\
28.2 \\
35.4 \\
34.2 \\
39.2\end{array}$ & $\begin{array}{l}3.5 \\
2.0 \\
1.0 \\
1.4 \\
4.3 \\
3.0 \\
4.5 \\
6.2 \\
\ddot{2} .4 \\
4.1 \\
2.0\end{array}$ & $\begin{array}{r}12.10 \\
17.10 \\
20.20 \\
20.20 \\
6.08 \\
11.30 \\
6.55 \\
5.03 \\
13 . .80 \\
14.80 \\
8.35 \\
19.70\end{array}$ \\
\hline
\end{tabular}

TABLE 7

Thie Formation of amino-acid and Ammonia from Peptone by B. Acidi-lactici Total Nitrogen $=304$ MgM. PER 100 c.c.

\begin{tabular}{|c|c|c|c|c|c|c|}
\hline \multirow{3}{*}{$\begin{array}{l}\text { Age of } \\
\text { Oulture } \\
\text { in } \\
\text { Days }\end{array}$} & \multicolumn{3}{|c|}{ Without Giucose } & \multicolumn{3}{|c|}{ With GJucose } \\
\hline & \multirow{2}{*}{$\begin{array}{l}\text { Amino- } \\
\text { acid } \\
\text { Nitro- } \\
\text { gen }\end{array}$} & \multirow{2}{*}{$\begin{array}{c}\text { Ammonia } \\
\text { Nitro- } \\
\text { gen }\end{array}$} & $\begin{array}{c}\text { Ratio: } \\
\text { Amino-acid N }\end{array}$ & \multirow{2}{*}{$\begin{array}{l}\text { Amino- } \\
\text { acid } \\
\text { Nitro- } \\
\text { gen }\end{array}$} & \multirow{2}{*}{$\begin{array}{c}\text { Ammonia } \\
\text { Nitro- } \\
\text { gen }\end{array}$} & $\begin{array}{c}\text { Ratio: } \\
\text { Amino-acid } \mathrm{N}\end{array}$ \\
\hline & & & Ammonia $\mathrm{N}$ & & & Ammonla N \\
\hline 0 & 42.4 & 3.5 & 12.10 & 42.4 & 3.5 & 12.10 \\
\hline 1 & 42.2 & 0.0 & $\ldots \ldots$ & 38.3 & 0.0 & $\ldots \ldots$ \\
\hline 2 & 49.5 & 2.8 & 17.70 & 44.5 & 3.0 & 12.80 \\
\hline 3 & 47.9 & 4.4 & 10.90 & 30.6 & 1.7 & 26.20 \\
\hline 4 & 38.0 & 4.7 & 8.48 & 38.8 & 5.9 & 5.19 \\
\hline 5 & 37.5 & 8.1 & 4.63 & 32.1 & 3.0 & 9.60 \\
\hline 6 & 29.9 & 6.8 & 4.40 & 34.6 & 5.4 & 5.95 \\
\hline 7 & 41.6 & 9.7 & 4.28 & 28.2 & 0.0 & $\cdots \cdots$ \\
\hline 9 & 34.5 & 12.2 & 2.83 & 36.8 & 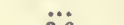 & …. \\
\hline 11 & 41.7 & 12.3 & 3.39 & 29.8 & 3.6 & 10.20 \\
\hline 14 & 47.8 & 14.4 & 3.32 & 33.9 & 4.8 & 6.22 \\
\hline 18 & 53.5 & 18.4 & 2.91 & $\ldots$ & 5.2 & 6.52 \\
\hline
\end{tabular}

TABLE 8

The formation of Amino-acid and Ammonia from Peptone by B. Ficcalis-Alkaligenes Total Nitrogen $=304 \mathrm{Mg}$. PER 100 c.c.

\begin{tabular}{|c|c|c|c|c|c|c|}
\hline \multirow{3}{*}{$\begin{array}{l}\text { Age of } \\
\text { Culture } \\
\text { in } \\
\text { Days }\end{array}$} & \multicolumn{3}{|c|}{ Without Glucose } & \multicolumn{3}{|c|}{ With Glucose } \\
\hline & \multirow{2}{*}{$\begin{array}{l}\text { Amino- } \\
\text { acid } \\
\text { Nitro- } \\
\text { gen }\end{array}$} & \multirow{2}{*}{$\underset{\substack{\text { Nitro. } \\
\text { gen }}}{\text { Ammonia }}$} & \multirow{2}{*}{$\begin{array}{c}\text { Ratio: } \\
\text { Amino-acid } N\end{array}$} & \multirow{2}{*}{$\begin{array}{l}\text { Amino- } \\
\text { acid } \\
\text { Nitro- } \\
\text { gen }\end{array}$} & \multirow{2}{*}{$\underset{\substack{\text { Nitro- } \\
\text { ged }}}{\text { Ammonia }}$} & $\begin{array}{c}\text { Ratio: } \\
\text { Amino-acid } N\end{array}$ \\
\hline & & & & & & Ammonia $\mathrm{N}$ \\
\hline 0 & 42.4 & 3.5 & 12.10 & 42.4 & 3.5 & 12.10 \\
\hline 1 & 37.7 & 0.0 & & 28.6 & 3.5 & 8.17 \\
\hline 2 & 52.8 & 2.6 & 20.30 & 36.1 & 3.5 & 10.30 \\
\hline 3 & 34.9 & 4.6 & 7.59 & 33.8 & 4.9 & 6.91 \\
\hline 4 & 25.0 & 5.1 & 4.90 & 32.6 & 5.7 & 5.72 \\
\hline 5 & 30.0 & 5.9 & 5.08 & 25.0 & 5.8 & 4.32 \\
\hline 6 & 31.5 & 7.0 & 4.50 & 25.2 & 7.7 & 4.42 \\
\hline 7 & 35.8 & 6.4 & 5.59 & 19.0 & 12.2 & 1.56 \\
\hline 9 & 36.8 & 6.1 & 6.04 & 27.5 & 6.5 & 4.23 \\
\hline 11 & 38.3 & 5.3 & 7.23 & 23.0 & 5.1 & 4.51 \\
\hline 14 & 38.9 & 3.4 & 11.40 & 28.0 & 5.1 & 5.49 \\
\hline 18 & 33.0 & 5.2 & 6.35 & 26.5 & 1.8 & 5.42 \\
\hline
\end{tabular}


TABLE 9

Tile Formation of Amino-acid and Ammonia from Peptone by B. Dysenteryie, Shiga Total Nitrogen $=304$ Mgm. PER 100 c.C.

\begin{tabular}{|c|c|c|c|c|c|c|}
\hline \multirow{3}{*}{$\begin{array}{c}\text { Age of } \\
\text { Culture } \\
\text { in } \\
\text { Dáys }\end{array}$} & \multicolumn{3}{|c|}{ Without Glucose } & \multicolumn{3}{|c|}{ With Glucose } \\
\hline & \multirow{2}{*}{$\begin{array}{l}\text { Amino- } \\
\text { acid } \\
\text { Nitro- } \\
\text { gen }\end{array}$} & \multirow{2}{*}{$\begin{array}{c}\text { Ammonia } \\
\text { Nitro- } \\
\text { gen }\end{array}$} & \multirow{2}{*}{$\frac{\begin{array}{c}\text { Ratio: } \\
\text { Amino-acid N }\end{array}}{\text { Ammonia } \mathbf{N}}$} & \multirow{2}{*}{$\begin{array}{l}\text { Amino- } \\
\text { acid } \\
\text { Nitro- } \\
\text { gen }\end{array}$} & \multirow{2}{*}{$\begin{array}{c}\text { Ammonia } \\
\text { Nitro- } \\
\text { gen }\end{array}$} & \multirow{2}{*}{$\frac{\begin{array}{c}\text { Ratio: } \\
\text { Amino-acid N }\end{array}}{\text { Ammonia N }}$} \\
\hline & & & & & & \\
\hline 0 & 42.4 & 3.5 & 12.1 & 42.4 & 3.5 & 12.1 \\
\hline 1 & 38.3 & 3.2 & 12.0 & 30.6 & 2.6 & 14.2 \\
\hline 2 & 49.1 & 3.8 & 12.9 & 34.9 & 1.5 & 33.0 \\
\hline 3 & 47.9 & 3.8 & 12,6 & 32.8 & 7.6 & 4.3 \\
\hline 4 & 36.6 & 4.7 & 7.8 & 30.2 & & \\
\hline 5 & 38.7 & 6.2 & 6.2 & 32.9 & 6.1 & 5.4 \\
\hline 6 & 26.5 & 1.2 & 6.3 & 30.8 & 6.6 & 4.7 \\
\hline 7 & 42,9 & 5.1 & 8.4 & 31.0 & 5.4 & 5.7 \\
\hline 9 & 44.3 & 7.9 & 5.6 & 25.8 & 8.8 & $2.9^{\circ}$ \\
\hline 11 & 43.6 & 6.5 & 6.7 & 33.2 & 5.5 & 6.0 \\
\hline 14 & 37.9 & 9.7 & 3.9 & 27.4 & 6.3 & 4.4 \\
\hline 18 & 43.4 & 5.9 & 7.4 & 27.5 & 2.6 & 10.6 \\
\hline
\end{tabular}

TABLE 10

Tue Formation of Amino-acid and Ammonia from Peptone by Stapiylococcus Pyogenes Total Nitrogen $=304 \mathrm{Mgm}$. per $100 \mathrm{c} . \mathrm{c}$.

\begin{tabular}{|c|c|c|c|c|c|c|}
\hline \multirow[b]{2}{*}{$\begin{array}{c}\text { Age of } \\
\text { Culture } \\
\text { In } \\
\text { Days }\end{array}$} & \multicolumn{3}{|c|}{ Without Glucose } & \multicolumn{3}{|c|}{ With Glucose } \\
\hline & $\begin{array}{l}\text { Amino- } \\
\text { acid } \\
\text { Nitro- } \\
\text { gen }\end{array}$ & $\begin{array}{c}\text { Ammonia } \\
\text { Nitro- } \\
\text { gen }\end{array}$ & $\frac{\begin{array}{c}\text { Ratio: } \\
\text { Amino-acid N }\end{array}}{\text { Ammonia N }}$ & $\begin{array}{l}\text { Amino- } \\
\text { acid } \\
\text { Nitro- } \\
\text { gen }\end{array}$ & $\underset{\substack{\text { Ammonitro- } \\
\text { gen }}}{ }$ & $\frac{\begin{array}{c}\text { Ratio: } \\
\text { Amino-acid } \mathrm{N}\end{array}}{\text { Ammonia } \mathrm{N}}$ \\
\hline $\begin{array}{r}0 \\
1 \\
2 \\
3 \\
4 \\
5 \\
6 \\
7 \\
8 \\
11 \\
14 \\
18\end{array}$ & $\begin{array}{c}42.4 \\
43.4 \\
43.2 \\
50.7 \\
39.3 \\
46.2 \\
31.8 \\
42.0 \\
\ldots \ldots \\
\ldots \ldots \\
\ldots . .\end{array}$ & $\begin{array}{c}3.5 \\
3.6 \\
5.2 \\
4.9 \\
8.5 \\
7.3 \\
\ldots .7 \\
7.7 \\
\ldots . \\
\ldots \\
\ldots\end{array}$ & $\begin{array}{r}12.1 \\
12.0 \\
8.3 \\
10.3 \\
4.6 \\
6.3 \\
\ldots \ldots \\
\ldots .5 \\
\ldots \ldots \\
\ldots \ldots \\
\ldots . .\end{array}$ & $\begin{array}{l}42.4 \\
37.5 \\
42.9 \\
43.5 \\
35.9 \\
40.6 \\
45.5 \\
41.0 \\
47.3 \\
47.8 \\
56.2 \\
62.5\end{array}$ & $\begin{array}{r}3.5 \\
3.2 \\
1.2 \\
3.5 \\
4.1 \\
2.8 \\
4.5 \\
10.2 \\
6.1 \\
6.0 \\
5.5 \\
5.2\end{array}$ & $\begin{array}{r}12.1 \\
11.7 \\
36.6 \\
12.4 \\
8.8 \\
14.5 \\
10.1 \\
40.2 \\
7.8 \\
8.0 \\
10.2 \\
12.0\end{array}$ \\
\hline
\end{tabular}

TABLE 11

The Formation of Amino-acid and Ammonia from Peptone by Sp. Metchnikovil Total Nitrogen $=304 \mathrm{MgM}$. Per 100 c.c.

\begin{tabular}{|c|c|c|c|c|c|c|}
\hline \multirow[b]{2}{*}{$\begin{array}{c}\text { Age of } \\
\text { Cuiture } \\
\text { in } \\
\text { Days }\end{array}$} & \multicolumn{3}{|c|}{ Without Glucose } & \multicolumn{3}{|c|}{ With Glucose } \\
\hline & $\begin{array}{l}\text { Amino- } \\
\text { acid } \\
\text { Nitro- } \\
\text { gen }\end{array}$ & $\begin{array}{c}\text { Ammonia } \\
\text { Nitro- } \\
\text { gen }\end{array}$ & $\frac{\begin{array}{c}\text { Ratio: } \\
\text { Amino-acid N }\end{array}}{\text { Ammonia } N}$ & $\begin{array}{l}\text { Amino- } \\
\text { acld } \\
\text { Nitro- } \\
\text { gen }\end{array}$ & $\begin{array}{c}\text { Ammonia } \\
\text { Nitro- } \\
\text { gen }\end{array}$ & $\begin{array}{c}\text { Ratio: } \\
\text { Amino-acid N }\end{array}$ \\
\hline $\begin{array}{r}0 \\
1 \\
2 \\
8 \\
4 \\
5 \\
6 \\
7 \\
9 \\
11 \\
14 \\
18\end{array}$ & $\begin{array}{r}42.4 \\
37.3 \\
50.9 \\
51.4 \\
56.9 \\
49.5 \\
55.5 \\
42.0 \\
75.9 \\
92.4 \\
91.7 \\
113.2\end{array}$ & $\begin{array}{r}3.5 \\
2.2 \\
6.5 \\
11.9 \\
15.3 \\
21.7 \\
29.8 \\
55.2 \\
27.0 \\
50.5 \\
41.6 \\
46.6\end{array}$ & $\begin{array}{r}12.1 \\
16.9 \\
7.8 \\
4.3 \\
3.7 \\
2.3 \\
1.8 \\
1.7 \\
2.7 \\
1.8 \\
2.2 \\
2.4\end{array}$ & $\begin{array}{l}42.4 \\
40.3 \\
39.1 \\
43.4 \\
41.2 \\
40.0 \\
43.9 \\
62.2 \\
40.0 \\
48.5 \\
52.8 \\
67.8\end{array}$ & $\begin{array}{r}3.5 \\
0.0 \\
1.2 \\
10.1 \\
9.3 \\
11.5 \\
11.1 \\
10.8 \\
11.7 \\
9.6 \\
11.3 \\
14.5\end{array}$ & $\begin{array}{r}12.1 \\
\ldots 3.6 \\
4.3 \\
4.4 \\
3.5 \\
4.0 \\
5.8 \\
3.4 \\
5.1 \\
4.7 \\
4.7\end{array}$ \\
\hline
\end{tabular}



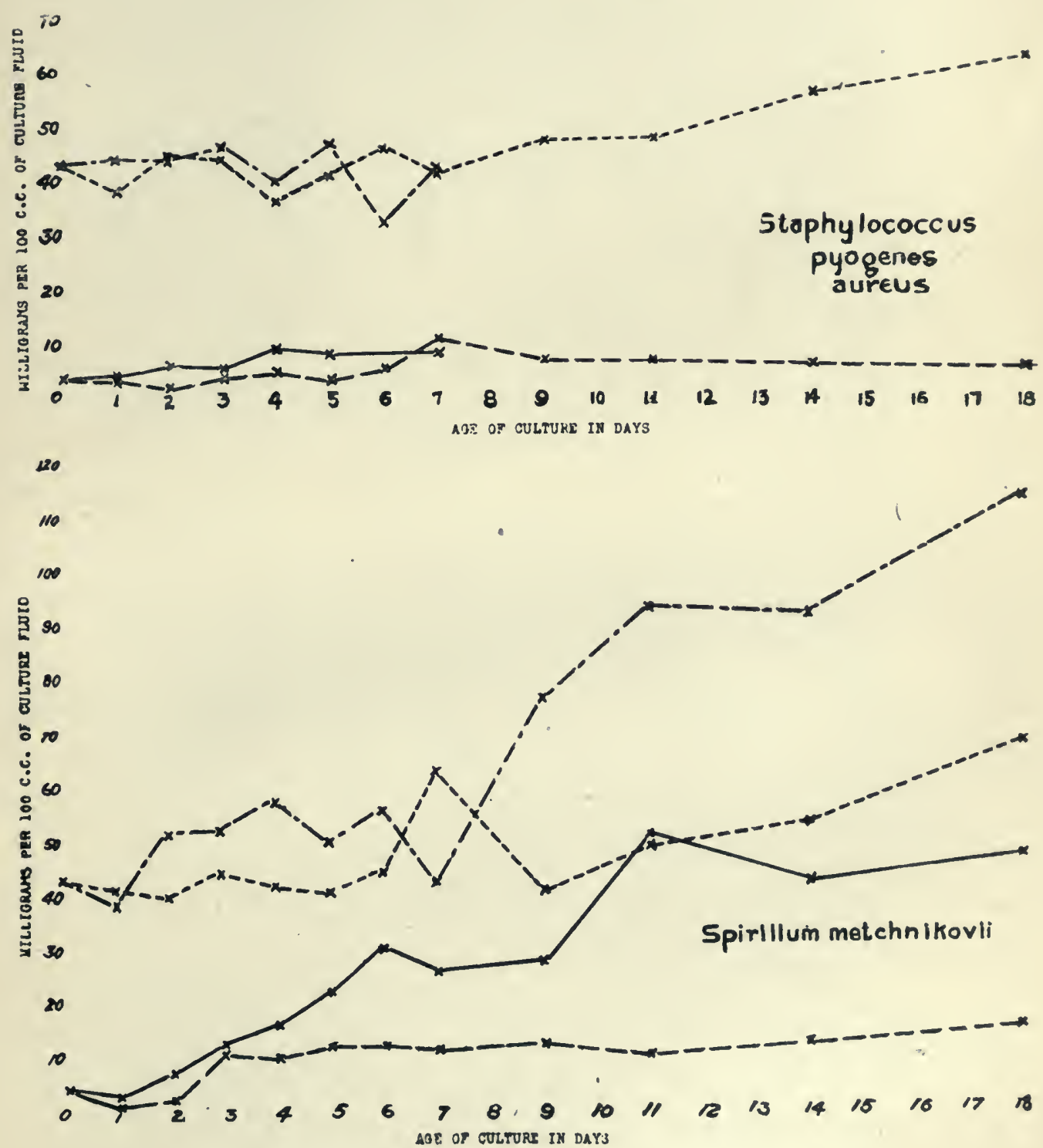

Chart 4. The formation by bacteria of amino-acid and ammonia from peptone. 
TABLE 12

$\therefore$

The formation of Amino-acid (ngammonia from Peptone yy B. Subtilis Total Nitrogen- $=304$ Mgm. Per 100 c.c.

\begin{tabular}{|c|c|c|c|c|c|c|}
\hline \multirow[b]{2}{*}{$\begin{array}{c}\text { Age of } \\
\text { Cuiture } \\
\text { In } \\
\text { Days }\end{array}$} & \multicolumn{3}{|c|}{ Without Glucgse } & \multicolumn{3}{|c|}{ With Glucose } \\
\hline & $\begin{array}{l}\text { Amino- } \\
\text { acid } \\
\text { Nitro- } \\
\text { gen }\end{array}$ & $\begin{array}{l}\text { Ammonia } \\
\text { Nitro- } \\
\text { gen }\end{array}$ & $\begin{array}{c}\text { Ratio: } \\
\text { Amino-acid N } \\
\text { Ammonia N }\end{array}$ & $\begin{array}{l}\text { Amino- } \\
\text { acid } \\
\text { Nitro- } \\
\text { gen }\end{array}$ & $\begin{array}{c}\text { Ammonia } \\
\text { Nitro- } \\
\text { gen }\end{array}$ & $\frac{\begin{array}{c}\text { Ratio: } \\
\text { Amino-acid } \mathrm{N}\end{array}}{\text { Ammonia } \mathrm{N}}$ \\
\hline $\begin{array}{r}0 \\
1 \\
2 \\
3 \\
4 \\
5 \\
6 \\
7 \\
9 \\
11 \\
14 \\
18\end{array}$ & $\begin{array}{r}42.4 \\
44.1 \\
60.1 \\
79.4 \\
86.8 \\
94.0 \\
100.0 \\
122.0 \\
117.5 \\
114.0 \\
101.2 \\
109.0\end{array}$ & $\begin{array}{r}3.5 \\
2.4 \\
13.9 \\
19.4 \\
29.4 \\
35.9 \\
48.1 \\
53.1 \\
55.5 \\
62.5 \\
68.7 \\
65.9\end{array}$ & $\begin{array}{r}12.1 \\
18.4 \\
4.3 \\
4.1 \\
2.9 \\
2.6 \\
2.0 \\
2.3 \\
2.1 \\
1.8 \\
1.5 \\
1.7\end{array}$ & $\begin{array}{r}42.4 \\
29.2 \\
42.1 \\
51.3 \\
50.2 \\
65.8 \\
71.0 \\
92.3 \\
97.8 \\
129.3 \\
112.0 \\
135.8\end{array}$ & $\begin{array}{r}3.5 \\
2.0 \\
4.3 \\
4.4 \\
8.5 \\
15.4 \\
20.1 \\
22.7 \\
31.1 \\
35.0 \\
37.8 \\
51.2\end{array}$ & $\begin{array}{r}12.1 \\
14.6 \\
9.8 \\
11.7 \\
5.9 \\
4.3 \\
3.5 \\
4.1 \\
3.1 \\
3.7 \\
3.0 \\
2.6\end{array}$ \\
\hline
\end{tabular}

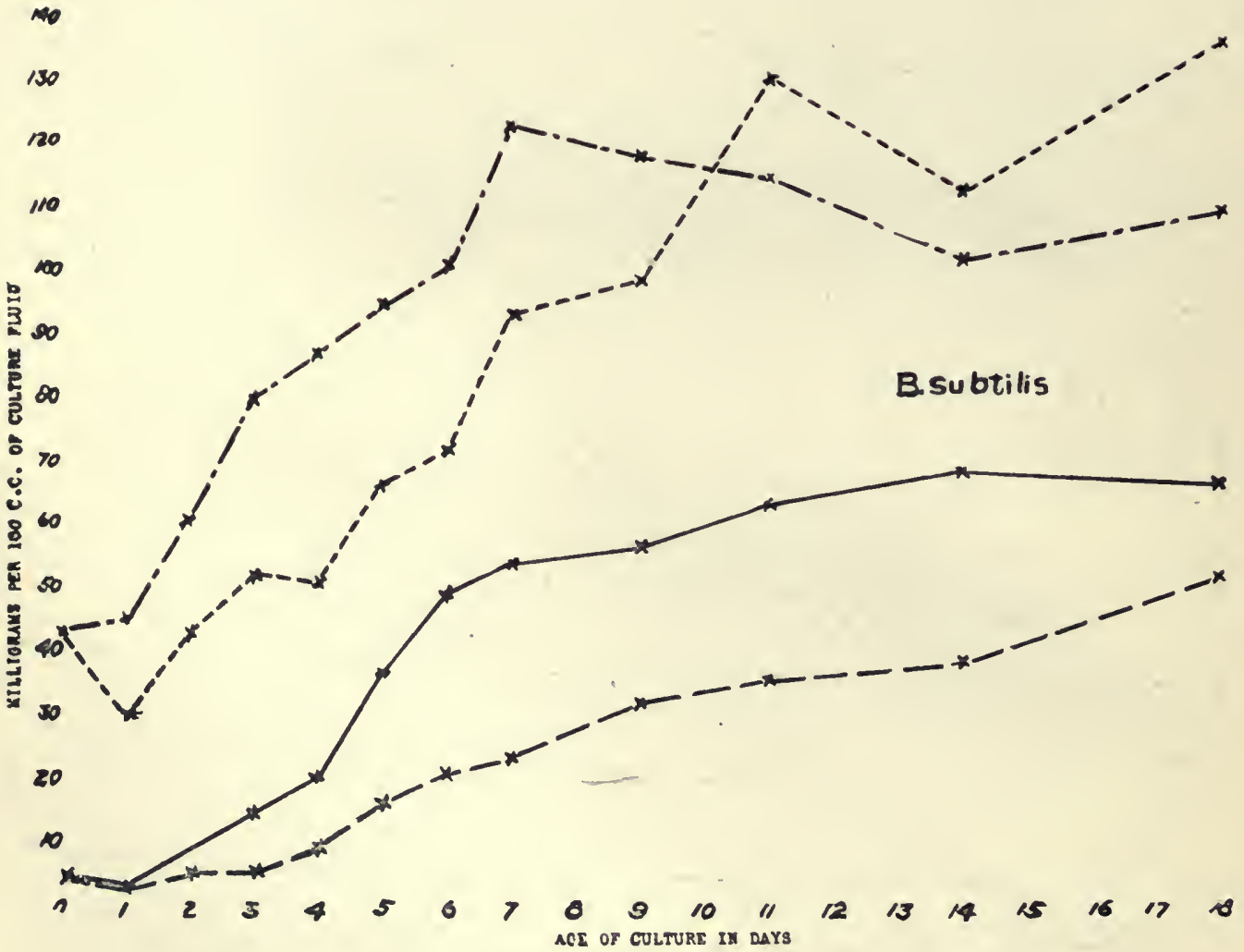

Chart 5. The formation by bacteria of aminn-acid and ammonia from peptonc. 
That the presence of glucose might decrease the peptone-splitting power of the cultures by preventing, to some extent, the reproduction of the organisms is contrary to experience, and would furthermore make the identical ammonia curves difficult to explain.

The decrease during the first 24-48 hours in the amount of free. ammonia which was originally present in the culture medium is noticed in the case of all the organisms studied. This decrease seems to take place to practically the same extent in the cultures containing glucose. It is undoubtedly true that in such cultures the most rapid multiplication of the organisms takes place during the first $24-48$ hours. It is therefore probable that this ammonia is utilized for the synthesis of bacterial protein. That ammonium salts are so utilized by certain micro-organisms when these salts are their only source of nitrogen is a well-established fact. But that such micro-organisms as those investigated should utilize anmonia in the presence of other forms of nitrogen seems at first a little surprising. A glance at the curves representing the concentrations of ammonia in the glucose-containing culture will show, however, that this compound is continuously utilized by the bacteria in question. Frequent decreases in concentration take place with all but the strongly proteolytic organism, B. subtilis. That the same decreases are not observed in the cultures not containing glucose is probably due to the greater proteolysis in the latter rather than to an increased assimilation of ammonia in the presence of the sugar. It is safe to assume that in no case does the ammonia found represent the entire amount formed by the organisms in the course of metabolism.

Also, an initial lowering of the amino-acid concentrations is observed in most of the cultures. This lowering is generally greater in the glucose-containing cultures, a fact which is doubtless explained by the decreased proteolytic activity in the latter.

In the cultures of B. subtilis and Sp. metchnikovii there is a tendency toward accumulation of amino-acids, both in the presence and in the absence of glucose. In the case of $\mathrm{B}$. subtilis this accumulation takes place after the first 24 hours at about an equal rate in both cultures until the 7th day is reached. After this the culture not containing the sugar shows a decrease while the one containing the sugar continues to show an increase at about the same rate. The maximal concentration of amino-acid in the case of the latter is not passed at the end of the experiment on the 18th day.

The ammonia curves of this organism are roughly parallel to the amino-acid curves. The sum of the amino-acid nitrogen and ammonia 
nitrogen in the non-glucose-containing culture on the 7 th day is nearly the same as the sum of these two substances in the glucose-containing culture on the 18th day, and is approximately equal to $3 / 5$ of the total nitrogen of the culture medium. Of all the cultures tested, that of Sp. metchnikovii shows the greatest reduction of proteolytic activity due to the presence of glucose. . In the sugar-containing culture of this organism the concentration of ammonia is uniformly low while in that free of sugar it reaches a value of $50.5 \mathrm{mgm}$., or about $17 \%$ of the total nitrogen of the medium. The amino-acid content of this culture attains the value of $113.2 \mathrm{mgm}$, or about $37 \%$ of the total nitrogen content. Taking into account, as will be pointed out later, the presence of other simple compounds of nitrogen, we can say that this organism in the absence of sugar is capable of decomposing almost completely a $2 \%$ solution of peptone. By the same reasoning $\mathrm{B}$. subtilis may be said to be capable of this even in the presence of $1 \%$ of glucose.

THE PRODUCTION OF AMINO-ACID AND AMMONIA BY BACTERIA IN MEDIA

\section{CONTAINING GELATIN}

The medium used in these tests was a $1 \%$ peptone solution containing $0.5 \%$ of $\mathrm{NaCl}$ to which was added $5 \%$ of pure gelatin. The medium was cleared by means of egg white, made neutral to phenolphthalein, and filtered until clear. To one half of the solution so prepared $1 \%$ of glucose was added. Both portions were then placed in 300-c.c. flasks, 200 c.c. to each. Calcium carbonate was added to the samples containing the carbohydrate. All the flasks were sterilized under 15 pounds' extra pressure for 10 minutes. They were then all inoculated at the same time and placed together in the same incubator at $37 \mathrm{C}$.

All the organisms used were capable of liquefying gelatin except B. faecalisalkaligenes and $\mathrm{B}$. cloacae. The strict anaerobe, B. aerogenes-capsulatus, and the facultative anaerobe, B. pyocyaneus, were grown under anaerobic conditions by keeping the surface of the medium covered with a thick layer of sterilized paraffin oil. Samples were removed at definite intervals by means of sterile pipets. These samples were heated in steam at $100 \mathrm{C}$. for one-half hour and at once subjected to analysis.

Tables 13 to 16 inclusive give the analytical results. The total nitrogen of the sterile medium was $828.6 \mathrm{mgm}$. per 100 c.c. B. subtilis shows much the same characteristics in its action on gelatin as on the peptone solution. It produces both amino-acid and free ammonia much more rapidly at first in the absence of glucose, but the rate of the production of these substances in the presence of the sugar increases in the later stages until, at the end of the 5 th week, the concentration of ammonia nitrogen is actually greater in this culture than in the culture containing no glucose and the concentration of the amino-acid nitrogen is nearly equal to that in the culture not containing glucose. 
TABLE 13

Tile Production of Amino-acid and Ammonia from Gelatin by Bacteria Total Nitrogen $=828.6 \mathrm{Mg}$. PER 100 c.c.

\begin{tabular}{|c|c|c|c|c|c|c|c|c|}
\hline \multirow{3}{*}{$\begin{array}{l}\text { Age } \\
\text { In } \\
\text { Days }\end{array}$} & \multicolumn{4}{|c|}{ B. Subtlils } & \multicolumn{4}{|c|}{ B. Cloacae } \\
\hline & \multicolumn{2}{|c|}{ Without Giucose } & \multicolumn{2}{|c|}{ Wjth Glucose } & \multicolumn{2}{|c|}{ Without GIucose } & \multicolumn{2}{|c|}{ With Giucose } \\
\hline & $\begin{array}{l}\text { Amino- } \\
\text { acid N }\end{array}$ & $\underset{\text { monia }}{\text { Am- }}$ & $\begin{array}{l}\text { Amino- } \\
\text { acid N }\end{array}$ & $\underset{\text { monia }}{\text { Am }}$ & $\begin{array}{l}\text { Amino. } \\
\text { acid } N\end{array}$ & $\underset{\text { monia }}{\text { Am }}$ & $\begin{array}{l}\text { Amino- } \\
\text { acid } N\end{array}$ & monia $N$ \\
\hline $\begin{array}{r}0 \\
1 \\
2 \\
4 \\
7 \\
10 \\
15 \\
24 \\
34\end{array}$ & $\begin{array}{r}42.5 \\
\dddot{79.2} \\
130.7 \\
206.8 \\
225.7 \\
225.1 \\
185.0 \\
172.0\end{array}$ & $\begin{array}{r}5.9 \\
\dddot{11} .4 \\
20.5 \\
65.2 \\
88.0 \\
73.5 \\
136.1 \\
133.4\end{array}$ & $\begin{array}{r}42.5 \\
\dddot{65.0} \\
97.3 \\
120.4 \\
140.4 \\
189.0 \\
185.0 \\
159.5\end{array}$ & $\begin{array}{r}5.9 \\
\ldots . . \\
5.2 \\
5.9 \\
0.0 \\
14.9 \\
39.0 \\
113.0 \\
164.3\end{array}$ & $\begin{array}{l}42.5 \\
58.0 \\
45.8 \\
69.3 \\
71.8 \\
56.9 \\
63.7 \\
62.8 \\
65.5\end{array}$ & $\begin{array}{r}5.9 \\
0.0 \\
0.0 \\
5.4 \\
9.2 \\
22.2 \\
33.3 \\
36.7 \\
43.5\end{array}$ & $\begin{array}{l}42.5 \\
45.7 \\
38.2 \\
52.3 \\
63.3 \\
44.8 \\
50.8 \\
82.6 \\
56.5\end{array}$ & $\begin{array}{r}5.9 \\
1.3 \\
0.0 \\
0.0 \\
0.0 \\
9.1 \\
27.2 \\
24.0 \\
50.7\end{array}$ \\
\hline
\end{tabular}

TABLE 14

The Production of Amino-acid and Ammonia from Gelatin by Bacteria

Total Nitrogen $=828.6 \mathrm{Mg}$. PER 100 c.c.

\begin{tabular}{|c|c|c|c|c|c|c|c|c|}
\hline \multirow{3}{*}{$\begin{array}{c}\text { Age } \\
\text { in } \\
\text { Days }\end{array}$} & \multicolumn{4}{|c|}{ B. Faecalis-Ajkaligenes } & \multicolumn{4}{|c|}{ B. Pyocyaneus, Aerobic } \\
\hline & \multicolumn{2}{|c|}{ Without Glucose } & \multicolumn{2}{|c|}{ With Glucose } & \multicolumn{2}{|c|}{ Without GJucose } & \multicolumn{2}{|c|}{ With Glucose } \\
\hline & $\begin{array}{l}\text { Amino- } \\
\operatorname{acid} \mathbf{N}\end{array}$ & $\underset{\text { monia }}{\text { Am }}$ & $\begin{array}{l}\text { Amino- } \\
\text { acid } N\end{array}$ & $\operatorname{Am}_{\text {monia }} N$ & $\begin{array}{l}\text { Amino- } \\
\text { acid N }\end{array}$ & $\begin{array}{c}\text { Am- } \\
\text { monla } N\end{array}$ & $\begin{array}{l}\text { Amino- } \\
\text { acld } \mathbf{N}\end{array}$ & ${ }_{\text {monla }}^{\text {Am }}$ \\
\hline $\begin{array}{r}0 \\
1 \\
2 \\
4 \\
7 \\
10 \\
15 \\
24 \\
34\end{array}$ & $\begin{array}{l}42.5 \\
51.8 \\
50.5 \\
54.7 \\
36.4 \\
55.4 \\
39.9 \\
63.7 \\
62.0\end{array}$ & $\begin{array}{r}5.9 \\
0.0 \\
0.0 \\
0.0 \\
0.0 \\
2.3 \\
7.0 \\
14.3 \\
14.7\end{array}$ & $\begin{array}{l}42.5 \\
8 . . . \\
85.5 \\
45.0 \\
38.8 \\
42.0 \\
38.2 \\
42.6 \\
46.8\end{array}$ & $\begin{array}{r}5.0 \\
\ldots .0 \\
0.0 \\
0.0 \\
0.0 \\
2.8 \\
6.5 \\
12.1 \\
18.1\end{array}$ & $\begin{array}{r}42.5 \\
\ldots \ldots .2 \\
50.2 \\
47.4 \\
87.6 \\
109.5 \\
279.0 \\
145.0 \\
161.0\end{array}$ & $\begin{array}{r}5.9 \\
1.8 \\
0.0 \\
2.8 \\
11.5 \\
21.9 \\
34.2 \\
49.7 \\
41.2\end{array}$ & $\begin{array}{r}42.5 \\
44.3 \\
44.3 \\
54.7 \\
48.7 \\
52.3 \\
55.0 \\
113.0 \\
202.4\end{array}$ & $\begin{array}{r}5.9 \\
0.0 \\
0.0 \\
0.0 \\
0.0 \\
0.0 \\
1.0 \\
18.6 \\
35.5\end{array}$ \\
\hline
\end{tabular}

TABLE 15

The Production of Amino-acid and Ammonia from Gezatin by Bacteria Total Nitrogen $=828.6$ mgm. Per 100 c.c.

\begin{tabular}{|c|c|c|c|c|c|c|c|c|}
\hline \multirow{3}{*}{$\begin{array}{l}\text { Age } \\
\text { in } \\
\text { Days }\end{array}$} & \multicolumn{4}{|c|}{ B. Pyocyaneus, Anaeroble } & \multicolumn{4}{|c|}{ B. Welchii } \\
\hline & \multicolumn{2}{|c|}{ Without Glucose } & \multicolumn{2}{|c|}{ With Glucose } & \multicolumn{2}{|c|}{ Without Glucose } & \multicolumn{2}{|c|}{ With Glucose } \\
\hline & $\begin{array}{l}\text { Amino- } \\
\text { acid N }\end{array}$ & $\underset{\text { monia } \mathrm{N}}{\text { Am- }}$ & $\begin{array}{l}\text { Amino- } \\
\text { acid N }\end{array}$ & ${ }_{\text {monia }}^{\text {Am- }}$ & $\begin{array}{l}\text { Amino- } \\
\text { acid N }\end{array}$ & $\underset{\text { monia } N}{\text { Am- }}$ & $\begin{array}{l}\text { Amino- } \\
\text { acid N }\end{array}$ & $\underset{\text { monia }}{\text { Am }}$ \\
\hline 0 & 42.5 & 5.9 & 42.5 & 5.9 & 42.5 & 5.9 & 42.5 & 5.9 \\
\hline 2 & $\dddot{55.4}$ & $\begin{array}{r}0.0 \\
\ldots . .\end{array}$ & $\dddot{48.6}$ & $\dddot{0} 0.0$ & $\dddot{47 . i}$ & $\begin{array}{l}0.0 \\
0.0\end{array}$ & $\dddot{49.3}$ & $\dddot{0.0}$ \\
\hline 4 & 48.7 & 0.0 & 59.7 & 0.0 & 79.1 & 0.0 & 186.4 & 19.9 \\
\hline 7 & 56.0 & 0.0 & 53.1 & 0.0 & 36.4 & 0.0 & 260.7 & 76.6 \\
\hline 10 & 67.3 & 5.7 & 34.4 & 2.8 & 56.3 & 0.0 & 277.2 & 92.2 \\
\hline 15 & 94.0 & 13.9 & 29.0 & 9.3 & 51.3 & 1.3 & 305.0 & 95.2 \\
\hline 24 & 159.1 & 34.7 & 105.3 & 17.8 & 66.2 & 3.2 & 303.0 & 85.7 \\
\hline 34 & 184.2 & 40.3 & 137.9 & 25.9 & 53.7 & 3.6 & 292.0 & 30.3 \\
\hline
\end{tabular}


TABLE 16

The Production of Amino-acid and Ammonia from Gelatin by Bacteria Total Nitrogen $=828.6$ Mgm. PER 100 c.c.

\begin{tabular}{|c|c|c|c|c|}
\hline \multirow{3}{*}{ Age in Days } & \multicolumn{4}{|c|}{ Sp. Cholerae } \\
\hline & \multicolumn{2}{|c|}{ Without Giucose } & \multicolumn{2}{|c|}{ With Glucose } \\
\hline & $\underset{N}{A m i n o-a c i d ~}$ & $\underset{N}{A m m o n i a}$ & $\underset{N}{\text { Amino-acid }}$ & $\underset{\mathbf{N}}{\operatorname{Ammonia}}$ \\
\hline 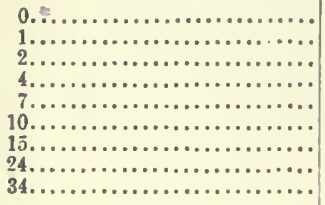 & $\begin{array}{r}42.5 \\
48.0 \\
58.0 \\
48.7 \\
89.7 \\
123.8 \\
174.0 \\
237.0 \\
265.3\end{array}$ & $\begin{array}{c}5.9 \\
0.0 \\
3.9 \\
0.0 \\
1.76 \\
30.4 \\
36.8 \\
78.1 \\
100.7\end{array}$ & $\begin{array}{l}42.5 \\
\dddot{49.5} \\
70.5 \\
40.7 \\
42.4 \\
41.8 \\
40.3 \\
45.1\end{array}$ & $\begin{array}{l}5.9 \\
\dddot{0.0} \\
0.0 \\
0.0 \\
0.2 \\
4.2 \\
8.3 \\
4.1\end{array}$ \\
\hline
\end{tabular}

The initial decrease in free ammonia is not observed in the sugarfree culture, probably because of the fact that a sample was not analyzed at the end of one day's incubation. This decrease is apparent, however, in the glucose-containing culture, and the latter also shows evidence of the continuous utilization of free ammonia in the falling off of the concentration from $5.9 \mathrm{mgm}$. per 100 c.c. on the 4th day to 0 on the 7th. Both the ammonia- and the amino-acid-production reach higher values than in the corresponding cultures on peptone alone. The sum of the two forms of nitrogen in the sugar-free culture does not differ greatly, on the last day of the experiment, from that in the case of the sugar-containing cultures, the two sums being approximately $37 \%$ and $39 \%$ respectively of the total nitrogen of the sterile medium.

The spirillum of Asiatic cholera offers a very interesting example of the protein-sparing action of glucose. In the concentrations of both amino-acid and free-ammonia the differences beween glucose and nonglucose cultures are enormous. The data show that in the absence of the carbohydrates the proteolytic activity of this organism is considerable, as great, in fact, as that of $\mathrm{B}$. subtilis or B. pyocyaneus. With glucose present, however, the indication is that the gelatin is attacked very little, if at all, since the figures are much lower even than those shown by this organism on a pure peptone medium (Table 3 ). It is evident that the effect of the sugar is continued throughout the entire time of the experiment. That chemical activity was not brought to a standstill by products of sugar-decomposition is evident from the fluctuating values of ammonia and amino-acid nitrogen. 
The data for B: cloacae and for B. faecalis-alkaligenes indicate that these two organisms are comparable with respect to their activity in the gelatin medium. The amino-acid concentrations are low in both cases. B. cloacae, however, forms comparatively large amounts of free ammonia, the rate of formation being slightly higher in the sugarfree culture. The amino-acid figures do not differ greatly in the two cultures of this organism. Considering the well-known utilization of glucose by $\mathrm{B}$. cloacae, it is surprising that its protein-sparing action is so little marked in this case. B. faecalis-alkaligenes lives up to its reputation in these cultures, also, in showing no decrease in its ammoniaproduction in the presence of glucose.

The two sets of cultures of B. pyocyaneus, the one grown under aerobic, the other under anaerobic conditions, furnish an instructive comparative study in the biochemistry of micro-organisms. The surprising fact in these data is that so little difference is shown between the two sets. On the whole the greater chemical activity seems to be shown in the cultures grown without the exclusion of oxygen. This difference is apparent, however, only during the first half of the period of the experiment. The effect of glucose is greater in the aerobic than in the anaerobic cultures. As multiplication appeared to be much slower in the latter, it is very likely that the differences which do exist are to be ascribed to differences in the numbers of organisms rather than to actual differences in the course or extent of chemical change due to the presence or absence of oxygen. Likewise, the apparently lowered protein-sparing effect of glucose in the anaerobic cultures is probably due to a difference between the numbers of organisms, for there was an unquestionably heavier growth in the anaerobic culture containing the sugar than in the sugar-free culture grown under the same conditions.

The cultures of B. welchii show this effect of glucose very plainly. The enormously greater chemical activity of this organism when grown with glucose can only be attributed to greatly increased multiplication in the presence of glucose. The appearance of the cultures fully substantiates this conclusion.

It will be observed from the data that the proteolytic activity of $\mathrm{B}$. welchii when grown under favorable conditions is considerable. As will be pointed out later, the nitrogen determined in the form of amino-acid and ammonia cannot be assumed to represent nearly all the nitrogen which is removed from its combinations in the protein molecule to form simpler compounds. 'When we consider, therefore, that 
on the 15 th day of incubation the nitrogen so determined, amounts to nearly $50 \%$ of the total nitrogen of the medium, we can scarcely agree with Rettger' $\mathrm{s}^{40}$ observation that this bacillus is primarily a fermenting organism.

The initial reduction in amount of the free ammonia which is originally present in the medium occurs in all of the cultures except the sugar-free culture of $B$. subtilis. The probable reason for this exception has already been suggested. In all cases this initial reduction takes place until the ammonia value actually reaches zero, and thereafter, in a number of the cultures, this compound remains absent for several days. This peculiar behavior was not shown by the pure peptone cultures and therefore it must be ascribed to the presence of gelatin. Obviously, the amino-acids resulting from the decomposition of this protein are broken down to the form of ammonia to a much smaller extent than those resulting from the splitting of Witte's peptone. Probably in the presence of an abundance of nourishment the decomposition is not carried so far.

\section{EVIDENCE OF THE EXISTENCE OF CONSIDERABLE QUANTITIES OF NITROGEN IN COMPOUNDS INTERMEDIARY BETWEEN AMINO-}

ACID AND AMMONIA

Investigators who have speculated on the manner in which the amino-acids resulting from protein-decomposition by micro-organisms are further broken down in the course of putrefaction have taught us to suppose that the first reaction to take place is deaminization with the splitting off of ammonia. ${ }^{41}$ This would mean, of course, that all the nitrogen of that group determined by the Van Slyke method, i. e., the alpha amino nitrogen, is transformed into ammonia. That this is not true in the case of the cultures investigated by us becomes evident when the tables are studied more carefully. Every decrease in aminoacid content which occurs in the interval between two analyses must represent, of course, the minimal amount of this form of nitrogen which has been altered during the period. If such alteration consisted in large part or entirely in deaminization, then the decrease should appear as a corresponding increase in ammonia nitrogen. The instances in which this is true in the data given are so rare as to be considered purely accidental. That this extra amount of amino-acid nitrogen metabolized could be to any considerable degree accounted for by ammonia lost through volatilization is made improbable from the following experiment: Five cubic centimeters of a $2 \%$ peptone

40 Jour. Biol. Chem., 1908, 4, p. 45.

41 Lafar: Handbuch der technischen Mykologie, 1904-1906, 3, p. 103. 
solution were placed in each of 6 tubes, sterilized, and inoculated severally with the organisms as indicated in Table 17 . After 15 days' incubation at $37 \mathrm{C}$. the tubes were again sterilized and the whole contents of. each submitted to a total nitrogen-determination. The results are given in Table 17 . The figures represent the total nitrogen in milligrams in the 5 c.c. of the corresponding culture.

TABLE 17

Nitrogen Lost from Bacterial Cultures by Volatilization

\begin{tabular}{|c|c|}
\hline Organism & $\begin{array}{l}\text { Milligrams of Total } \\
\text { Nitrogen In } 5 \text { c.c. of } \\
\text { Culture Medium After } \\
15 \text { Days' Incubation }\end{array}$ \\
\hline 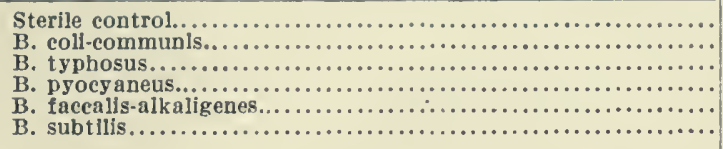 & $\begin{array}{l}15.95 \\
15.64 \\
15.94 \\
15.61 \\
15.72 \\
14.39\end{array}$ \\
\hline
\end{tabular}

It is seen that B. subtilis is the only one of the organisms investigated in this respect which lost any appreciable quantity of nitrogen during the 15 days' incubation. Even its loss could by no means account for the differences mentioned. Berghaus ${ }^{42}$ also gives data on the loss of ammonia through volatilization. Tho ammonia is undoubtedly utilized to a certain. extent by most of the species studied, the amount utilized must necessarily be small. That part of it which is used for the synthesis of bacterial protein or the metabolism of which results in compounds which are not volatile could not be great enough to be considered in the present connection.

The only conclusion which can be drawn from the facts in the case, therefore, is that the greater part of the reported losses in aminoacid nitrogen which take place from time to time is due to the conversion of this nitrogen into compounds other than ammonia. Further, the continued low concentration or the entirc absence of the latter, as seen particularly in the gelatin cultures, during the first days of the experiments, points to the conclusion that ammonia arises from the decomposition of these other compounds, and that the latter are therefore to be regarded as important stages in the complete decomposition of protein. That some of them are true end products, and undergo no further change through the action of the micro-organism concerned is evidenced by the slight extent to which creatin is attacked by $B$. proteus (Table 5), which, as seen in Table 1 , is capable of forming this substance from peptone.

42 Arch. f. Hyg., 1907, 64, p. 1. 

THE FORMATION BY BACTERIA OF UREA, URIC ACID, ALLANTOIN,
CREATIN, AND CREATININ

Urea and Uric Acid.-All the peptone cultures described thus far in this paper were examined in several stages of their growth for urea and uric acid. Neither of these compounds was found in any case.

The urease method originated by Van Slyke ${ }^{43}$ was used for the detection of the former, and the colorimetric method used by Folin and Denis, ${ }^{4}$ for the latter. Both these methods were proved to be efficient by determinations made on cultures to which weighed amounts of the pure chemicals had been added. The medium used in the case of uric acid was a solution containing $10 \mathrm{gm}$. asparagin, $2.5 \mathrm{gm}$. $\mathrm{Na}_{2} \mathrm{CO}_{3}, 2 \mathrm{gm}$. $\mathrm{Na}_{2} \mathrm{HPO}_{4}$, traces of $\mathrm{MgSO}_{4}$ and $\mathrm{CaCl}_{2}$ and $0.902 \mathrm{gm}$. of uric acid per liter. The time of incubation was 15 days. The medium used in the case of urea was a $2 \%$ peptone solution containing about $10 \mathrm{gm}$. of urea per liter. The cultures were incubated for 7 days.

TABLE 18

Decomposition of Uric $\Lambda$ Cid by Bacteria

\begin{tabular}{|c|c|c|c|}
\hline Organism & $\begin{array}{l}\text { Ammonia Nitro- } \\
\text { gen per } 100 \text { c.c. } \\
\text { Culture Medium }\end{array}$ & $\begin{array}{l}\text { Amino-acid Nitro- } \\
\text { gen per } 100 \text { c.c. } \\
\text { Culture Medium }\end{array}$ & $\begin{array}{c}\text { Uric Acid } \\
\text { per } 100 \text { c.c. } \\
\text { Culture Medium }\end{array}$ \\
\hline 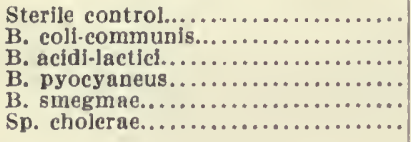 & $\begin{array}{l}5.3 \mathrm{mgm} . \\
112.0 \mathrm{mgm} \\
102.6 \mathrm{mgm} \\
39.1 \mathrm{mgm} \\
43.2 \mathrm{mgm} \\
41.5 \mathrm{mgm}\end{array}$ & $\begin{array}{l}94.5 \mathrm{mgm} . \\
36.0 \mathrm{mgm} \text {. } \\
7.3 \mathrm{mgm} \text {. } \\
22.5 \mathrm{mgm} \text {. } \\
68.0 \mathrm{mgm} \\
32.6 \mathrm{mgm}\end{array}$ & $\begin{array}{l}65.7 \text { mgm. } \\
7.5 \text { mgm. } \\
\text { None } \\
\text { None } \\
\text { None } \\
\text { None }\end{array}$ \\
\hline
\end{tabular}

TABLE 19

DECOMPOSITION OF L'REA BY RACTERIA

\begin{tabular}{|c|c|c|c|}
\hline Organism & $\begin{array}{l}\text { Ammonia } \\
\text { Nitrogen } \\
\text { in } 5 \text { c.c. } \\
\text { Culture Fluid }\end{array}$ & $\begin{array}{c}\text { Urea } \\
\text { Nitrogen } \\
\text { in } 5 \text { c.c. } \\
\text { Culture Fluid }\end{array}$ & $\begin{array}{l}\text { Nitrogen of Urea } \\
\text { Decomposed } \\
\text { in } 5 \text { c.c. } \\
\text { Culture Fluid }\end{array}$ \\
\hline 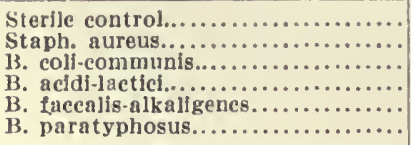 & $\begin{array}{l}\text { None } \\
3.03 \mathrm{mgm} \text {. } \\
3.12 \mathrm{mgm} \text {. } \\
2.31 \mathrm{mgm} \text {. } \\
0.52 \mathrm{mgm} \text {. } \\
2.24 \mathrm{mgm} \text {. }\end{array}$ & $\begin{array}{r}22.28 \mathrm{mgm} . \\
21.75 \mathrm{mgm} . \\
21.23 \mathrm{mgm} . \\
15.48 \mathrm{mgm} \text {. } \\
6.73 \mathrm{mgm} . \\
6.37 \mathrm{mgm} \text {. }\end{array}$ & $\begin{array}{l}\text { None } \\
0.53 \mathrm{mgm} \text {. } \\
1.05 \mathrm{mgm} \text {. } \\
6.80 \mathrm{mgm} \text {. } \\
15.45 \mathrm{mgm} \\
15.81 \mathrm{mgm} \text {. }\end{array}$ \\
\hline
\end{tabular}

* In this test inoculations were made into 5-c.c. portions of the culture medium, aud the tubes were incubated for 7 days.

It is not surprising that uric acid and urea are not to be found in bacterial cultures when it is considered how easily and completely both are decomposed by bacteria. Tables 18 and 19 give the results of brief tests designed to show this.

Allantoin.-Numerous attempts were made to prove the presence of allantoin in cultures on pure peptone solutions as well as in those on peptone solutions containing uric acid, but it was impossible to find

4s Van Slyke and Cullen: Proc. Soc. Exper. Biol. and Med., 1913, 11, p. 56.

14 Jour. Biol. Chem., 1913, 14, p. 95. 
a method by which all interfering substances were excluded. The Wiechowski ${ }^{45}$ method, for which great accuracy is claimed in the determination of allantoin in urine, was employed repeatedly, but without success.

This method consists in precipitation by phosphotungstic acid, the removal of the excess of this reagent by means of lead oxid and acetic acid, the elimination of the chlorid with silver acetate, and the final precipitation of all heavy metals with hydrogen sulfid. After removal of the latter by aeration the solution is made alkaline with magnesium oxid and the allantoin precipitated by means of a solution consisting of $20 \%$ sodium acetate and $1 \%$ mercuric acetate.

It was found that in all bacterial cultures on peptone media a precipitate was obtained at this point which had a varying, in some cases high, total-nitrogen content. Morcover, the sterile control usually gave a precipitate here also, which varied from a slight opalescence to an appreciable deposit. It was not possible to prepare the characteristic crystals of allantoin from any of these precipitates. It is probable that the latter consisted, in the most part, of aminoacids which escaped precipitation by the phosphotungstic acid. Levene and Beatty ${ }^{40}$ showed that many of these acids are precipitated completely by this reagent only when it is present in very high concentration. Such concentrations would be entirely impractical in the present connection.

Attempts to show that uric acid is decomposed by bacteria with the formation of allantoin were unsuccessful for the same reasons as have just been outlined. A medium having asparagin as the nitrogenous base was also used in these experiments. The Wiechowski method was inapplicable here also, since asparagin, not being precipitated by phosphotungstic acid, is brought down with the allantoin by the sodium-acetate mercuric-acetate reagent. If allantoin was ever present in this precipitate, it was there in such small quantities that it could not be detected in the presence of asparagin.

This inability to separate allantoin from asparagin would seem to render the Wiechowski method inapplicable also to the determination of allantoin in plants. In fact, it has been shown recently in this laboratory that a very large portion of the nitrogen determined as allantoin in plant tissue by this method is in reality asparagin, where this substance is present in considerable amounts.*

The problem of the formation of allantoin by bacteria seems to depend for its solution on the perfection of the methods for the determination of this compound and its separation from interfering substances.

Creatin and Creatinin.-Most of the peptone cultures or peptone solutions reported in the first part of this paper were tested for creatin and creatinin. In general, the results were in close agreement with those of Fitzgerald and Schmidt. ${ }^{22}$ That is, only B. proteus was found to form appreciable amounts of creatinin on solutions of peptone alone. It was found however that in those cultures containing glucose, a test for this substance and for creatin gave positive results in a large num-

4s Neubauer's Analyse des Harns, 1913, 2, p. 1076.

16 Levene and Beatty, Ztschr. f. physiol.'Chem., 1906, 47, p. 149.

* Yet unpublished thesis of G. C. Swan, Stanford University, May, 1915. 
ber of cases. More careful investigation of this subject was considered important, and the following experiment was therefore carried out:

A large amount of $2 \%$ peptone solution containing $0.5 \% \mathrm{NaCl}$ was divided in half and to one portion $1 \%$ glucose was added. The two portions were placed in sterile flasks, 100 c.c. to each, and sterilized in the autoclave for 10 minutes. The flasks were then inoculated and placed in the incubator at $37 \mathrm{C}$. Each organism to be tested was iroculated into a flask containing glucose and into one not containing glucose.

Folin ${ }^{47}$ claimed accuracy for his methods for the determination of creatin and creatinin in the presence of considerable quantities of glucose. Nevertheless, it was considered essential to maintain two sterile controls, one with, and one without, glucose. Samples were withdrawn from each of the cultures and from the controls at definite intervals and after sterilization in steam at $100 \mathrm{C}$, they were subjected to analysis for creatinin and creatin, by Folin's methods.

Tables 20 and 21 give the results of these analyses. The values are in milligrams per 100 c.c. The fact that neither of the sterile controls gave at any time a color reaction seems sufficient to establish at once the noninterference of glucose with the determinations. We may assume, therefore, that the figures given indicate with reasonable accuracy the comparative creatinin- and creatin-forming power of the micro-organisms in question.

It will be observed that only B. proteus and Sp. cholerae form both creatin and creatinin in the absence of sugar. B. subtilis forms creatin but not creatinin. Of the cultures on the glucose-containing solutions, only $\mathrm{B}$. faecalis-alkaligenes fails to give the reaction for creatinin. This culture shows on the second day a considerable quantity of creatin. Tests for this substance thereafter, however, are all negative.

Examination of the tables will suggest that there are several possibilities for the differentiation of species by this method. For example, on the second day the amount of creatinin in the culture of $B$. typhosus is $5.9 \mathrm{mgm}$. per $100 \mathrm{c.c}$., an amount which is easily detectable in a 5-c.c. portion. The corresponding cultures of B. coli and B. faecalis-alkaligenes both are negative in the test for creatinin. Likewise, Sp. cholerae gives $6.6 \mathrm{mgm}$. of creatinin on the second day, while the morphologically and culturally similar organism, Sp. metchnikovii, gives only a trace. It is interesting to note that in the point of their creatin-production all five of the organisms mentioned, show just the reverse characteristics; the cultures of B. coli, B. faecalis-alkaligenes, and Sp. metchnikovii show high concentration, while those of $B$. typhosus and Sp. cholerae give low values for this compound.

In most of the cultures the maximal concentration of both creatin and creatinin seemed to be reached from about the 5 th to the 8 th days.

4. Jour. Biol. Chem., 1914, 17, p. 475. 
After that the amount seemed to suffer some decrease. In the case of $\mathrm{B}$. pyocyaneus and $\mathrm{B}$. subtilis a maximum is not shown in the time of the experiment. The creatinin content in the culture of Staph. pyogenes shows a continuous increase, but its creatin content falls nearly to zero after the second day.

TABLE 20

Formation of Creatinin in Peptone Cultures of Micro-organisas

\begin{tabular}{|c|c|c|c|c|c|c|c|c|}
\hline \multirow{2}{*}{ Culture } & \multicolumn{2}{|c|}{2 Days Old } & \multicolumn{2}{|c|}{5 Days Oid } & \multicolumn{2}{|c|}{8 Days Old } & \multicolumn{2}{|c|}{14 Days Old } \\
\hline & $1^{*}$ & $2^{*}$ & 1 & 2 & 1 & 2 & 1 & 2 \\
\hline B. proteus-vulgaris........... & - & 3.4 & Trace & 4.5 & 2.6 & 5.1 & 4.6 & 5.8 \\
\hline B. pyocyaneus................. & - & 4.0 & - & 6.3 & - & 9.4 & - & 23.1 \\
\hline 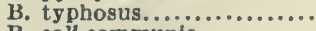 & - & 5.9 & - & 8.0 & - & 6.8 & - & 6.9 \\
\hline B. coli-communis.............. & - & - & - & 5.2 & - & 3.2 & - & Trace \\
\hline Sp. cholerae.................. & - & 6.6 & - & 8.8 & 2.9 & 10.4 & - & Trace \\
\hline B. subtilis.................... & - & - & - & 5.6 & - & 14.6 & - & 25.0 \\
\hline B. paratyphosus............. & - & 5.1 & - & 7.3 & - & 5.9 & - & 6.1 \\
\hline B. cloacae........................ & - & 3.9 & - & 4.4 & - & 4.7 & - & - \\
\hline B. faecalls-alkaligenes....... & - & - & - & - & - & & - & - \\
\hline Sp. metchnikovil............ & - & Trace & - & Trace & - & 4.7 & - & 7.3 \\
\hline Staph. pyogenes.............. & - & Trace & - & 3.5 & - & 5.0 & - & 11.6 \\
\hline B. dysenteriae, Shiga....... & - & 3.8 & - & 4.1 & - & 5.4 & - & 5.7 \\
\hline B. acidi-lacticl............... & - & 3.7 & - & 4.2 & - & 5.0 & - & 5.1 \\
\hline B. prodiglosus................. & - & Trace & - & 3.2 & - & 4.5 & - & 4.7 \\
\hline Sterile controis............... & - & - & - & - & - & - & - & - \\
\hline
\end{tabular}

* The numbers 1 and 2 refer to the glucose-free and the glucose-containing cuitures, respectively.

TABLE 21

lormation of Creatin in Peptone Cultures of Micro-organisms

\begin{tabular}{|c|c|c|c|c|c|c|c|c|}
\hline \multirow{2}{*}{ Culture } & \multicolumn{2}{|c|}{2 Days Old } & \multicolumn{2}{|c|}{5 Days Oid } & \multicolumn{2}{|c|}{8 Days Old } & \multicolumn{2}{|c|}{14 Days Oid } \\
\hline & $1^{*}$ & $2^{*}$ & 1 & 2 & 1 & 2 & 1 & 2 \\
\hline B. proteus-vulgaris.......... & - & 2.2 & Trace & 3.9 & 5.9 & 5.3 & 8.5 & 3.1 \\
\hline B. pyocyaneus............... & - & 6.8 & - & 15.7 & - & $t$ & $t$ & $\dagger$ \\
\hline 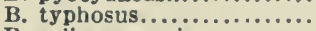 & - & 3.0 & - & 6.4 & - & 5.5 & - & 3.9 \\
\hline B. coll-commun is............ & - & 7.2 & - & 4.8 & - & 5.3 & - & - \\
\hline Sp. cholerac................. & - & 2.3 & - & 8.6 & 4.7 & 6.5 & - & + \\
\hline 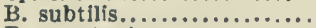 & - & 6.7 & - & 7.7 & 72 & & $t$ & 13.1 \\
\hline B. paratyphosus........... & - & 2.4 & - & 5.3 & - & $\dddot{6} .0$ & - & f.fi \\
\hline B. cloacac................. & - & 3.9 & - & 5.0 & - & 8.8 & - & - \\
\hline B. faccalis-alkaligenes........ & - & 9.8 & - & - & & - & - & - \\
\hline Sp. metchnikovil............ & - & 10.1 & - & 4.3 & - & 0.4 & - & 7.5 \\
\hline Staph. pyogenes............ & - & 7.6 & - & 1.5 & - & - & - & 1.8 \\
\hline B. dy senteriae, Shiga....... & - & 7.3 & - & 1.9 & - & 0.3 & - & 5.8 \\
\hline B. aeldi-1acticl............. & - & 5.4 & -. & 2.8 & - & - & $\rightarrow$ & 3.2 \\
\hline B. prodiglosus.............. & - & 10.7 & - & 2.1 & - & - & - & 7.1 \\
\hline Sterile controis.............. & - & & - & - & - & - & - & - \\
\hline
\end{tabular}

* The numbers 1 and 2 refer to the glucose-free and the glucose-containing cuitures, respectlvely.

+ When the reagent was added to these samples, a very dark color was produced, which could not be matched with the standard creatinin solution.

There seem to be two possible explanations of this surprising effect of glucose on creatin- and creatinin-production by micro-organisms. Either these substances are regularly produced by bacteria in peptone solutions and their decomposition as fast as formed prevented by the presence of sugar, or else glucose, or some of its split products, actually takes part in the synthesis by the organisms of these two nitrogenoris 
compounds. The former seems to be the more probable of the two hypotheses. Fortunately, this proposition is susceptible of proof; at least, strong evidence for or against it may be obtained by investigating the effect of glucose on the decomposition by micro-organisms of quantities of creatin and creatinin added to peptone solution.

TABLE 22

Tile Decomposition of Creatinin gy Bacteria

\begin{tabular}{|c|c|c|c|c|c|c|}
\hline \multirow{2}{*}{ Culture } & \multicolumn{2}{|c|}{2 Days Old } & \multicolumn{2}{|c|}{6 Days Old } & \multicolumn{2}{|c|}{15 Days Old } \\
\hline & $\begin{array}{l}\text { Glucose } \\
\text { Present }\end{array}$ & $\begin{array}{l}\text { Glucose } \\
\text { Absent }\end{array}$ & $\begin{array}{l}\text { Glucose } \\
\text { Present }\end{array}$ & $\begin{array}{c}\text { Glucose } \\
\text { Absent }\end{array}$ & $\begin{array}{l}\text { Glucose } \\
\text { Present }\end{array}$ & $\begin{array}{l}\text { Glucose } \\
\text { Absent }\end{array}$ \\
\hline 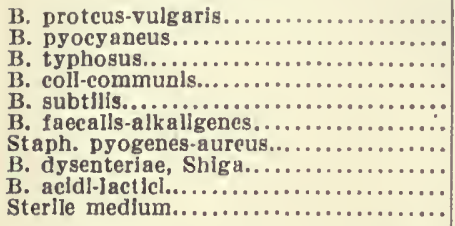 & $\begin{array}{l}52.4 \\
51.3 \\
48.1 \\
41.3 \\
41.8 \\
56.5 \\
47.4 \\
56.9 \\
50.7 \\
54.6\end{array}$ & $\begin{array}{l}47.1 \\
53.3 \\
53.9 \\
56.2 \\
54.2 \\
54.1 \\
13.4 \\
53.6 \\
45.2 \\
54.6\end{array}$ & $\begin{array}{l}36.9 \\
29.3 \\
42.0 \\
33.6 \\
51.8 \\
46.8 \\
48.7 \\
48.1 \\
53.2 \\
55.6\end{array}$ & \begin{tabular}{c|}
31.9 \\
38.3 \\
42.4 \\
44.6 \\
53.6 \\
55.5 \\
Trace \\
51.4 \\
32.7 \\
55.5
\end{tabular} & $\begin{array}{l}32.3 \\
* \\
48.2 \\
32.9 \\
54.8 \\
48.8 \\
44.1 \\
51.8 \\
58.2 \\
55.1\end{array}$ & $\begin{array}{c}32.3 \\
\text { Trace } \\
50.0 \\
\text { Trace } \\
57.1 \\
52.2 \\
\text { Trace } \\
51.6 \\
34.8 \\
55.3\end{array}$ \\
\hline
\end{tabular}

- The solution was too dark-colored to be comparable with the standard.

An experiment similar to the one just described, but with a $2 \%$ peptone solution containing in each liter the juice from $1 \mathrm{lb}$. of lean beef as the medium used, was carried out. Only creatinin determinations were made. The same method was used as in the former experiment. Samples of 2 c.c. were used for most of the determinations.

Table 22 gives the results of the test. As in all the preceding tables, the values are given in milligrams per 100 c.c. of the culture fluid. The data seem to be in accord with the explanation already suggested of the effect of glucose on the formation of creatin and creatinin by bacteria. The latter compound is decomposed in most cases to a considerably less extent when glucose is present in the medium. The very great effect of this substance in the case of the staphylococcus cultures is worthy of special mention. It is also interesting that the cultures of $\mathrm{B}$. faecalis-alkaligenes and of B. dysenteriae show the same absence of the sparing effect of sugar as they did in the case of the peptone solutions.

Further experiments are now in progress on this phase of bacterial metabolism, and it is to be hoped that more definite information may be obtained on the part played by glucose in these reactions.

\section{SUMMARY}

Peptone cultures of most bacteria give fluctuating concentrations of amino-acid, showing that these bodies are formed and broken down continuously by the organisms. 
A few strongly proteolytic organisms are exceptions to the rule in that their cultures show steadily increasing concentrations of aminoacid. Among these are B. pyocyaneus, B. subtilis, Sp. cholerae, and Sp. metchnikovii.

Most species, when grown in peptone or peptone gelatin media, show an inclination to utilize the simpler compounds of nitrogen before attacking the protein or peptone.

Most species also show evidences of a continuous utilization of ammonium salts in small amounts.

The general phenomenon of the protein-sparing effect of glucose is evident in most cultures not only from their concentrations of freeammonia, but also from their concentrations of amino-acid, and, in fact, may be disclosed by the latter when the former fails to give evidence of it, as is true in the case of B. faecalis-alkaligenes and B. dysenteriae, Shiga.

Practically the same characteristics of ammonia- and amino-acidproduction are shown by the organisms on peptone solutions coritaining $5 \%$ gelatin as on pure peptone solutions, except that the concentrations in the former media are much greater in the case of those organisms having a gelatin-liquefying power.

The ammonia and amino-acid curves of $\mathrm{B}$. pyocyaneus grown aerobically do not differ materially from those of the same organism grown anaerobically.

B. welchii, when grown under favorable conditions, shows very strong proteolytic activity.

The free ammonia and amino-acid curves of most micro-organisms give evidence of the existence in their cultures of large amounts of nitrogenous products intermediary between amino-acid and ammonia.

Urea and uric acid are not found in peptone cultures of bacteria, probably because of the ease with which these substances are decomposed by most species.

No method could be found for the detection and determination of allantoin which was applicable to peptone cultures or to cultures containing asparagin.

A few species of bacteria are capable of producing creatin and creatinin in sugar-free peptone cultures. Many more are capable of producing these substances in peptone media containing glucose, the probable reason for this effect of the sugar being its sparing action for the two compounds in question. 


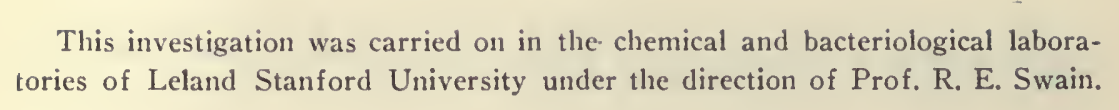


(a)

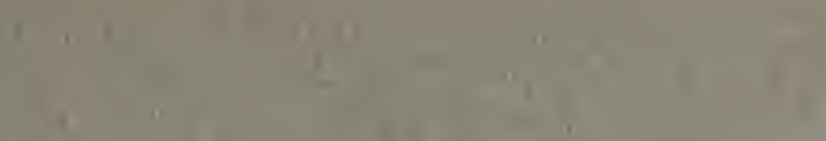

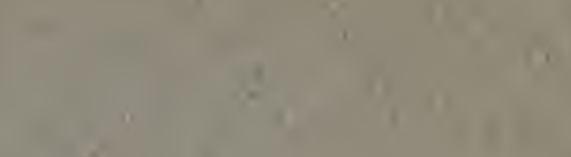

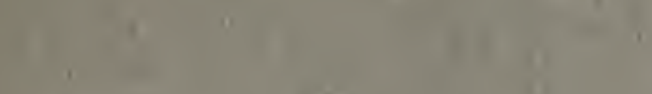

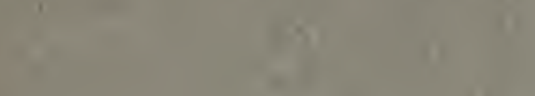

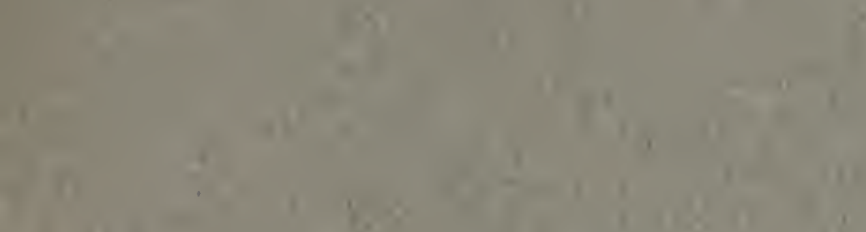

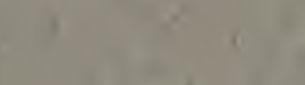

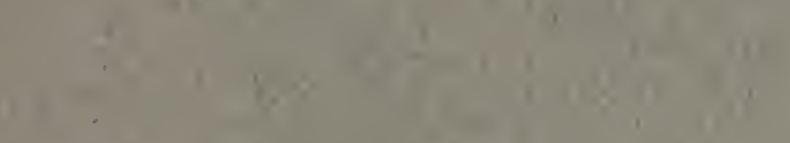

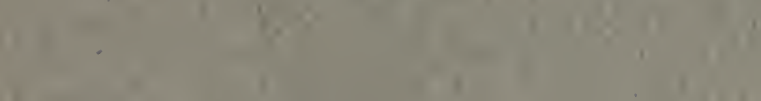

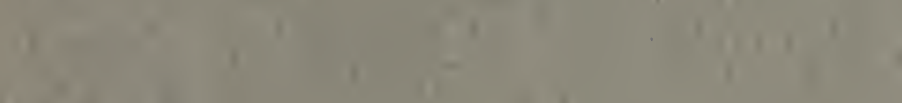

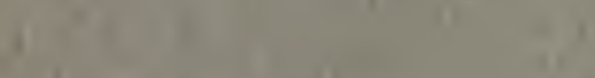

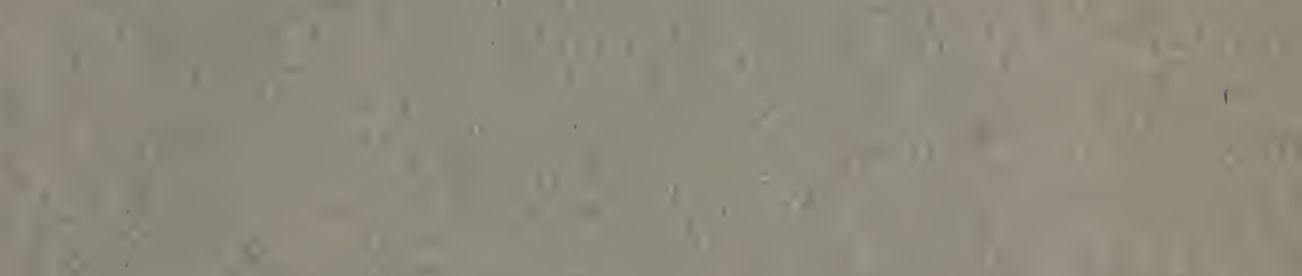

1
1
1

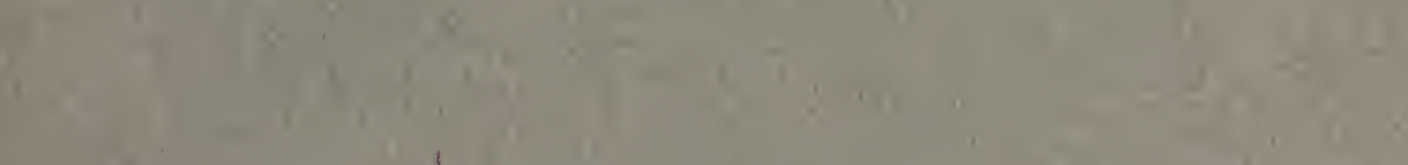

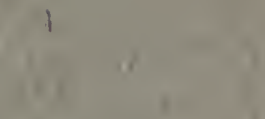

$-i y$

II

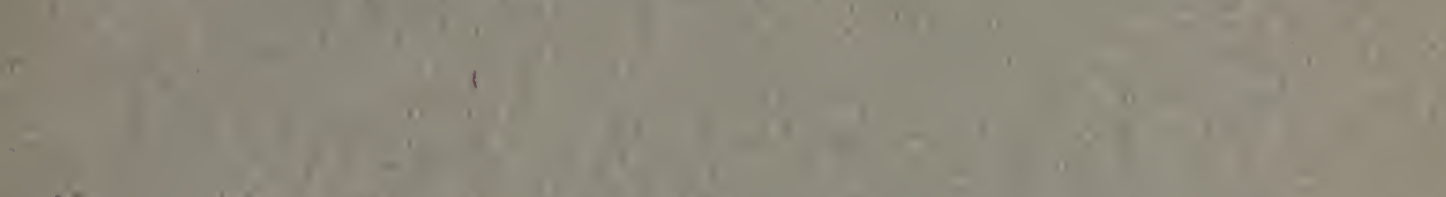

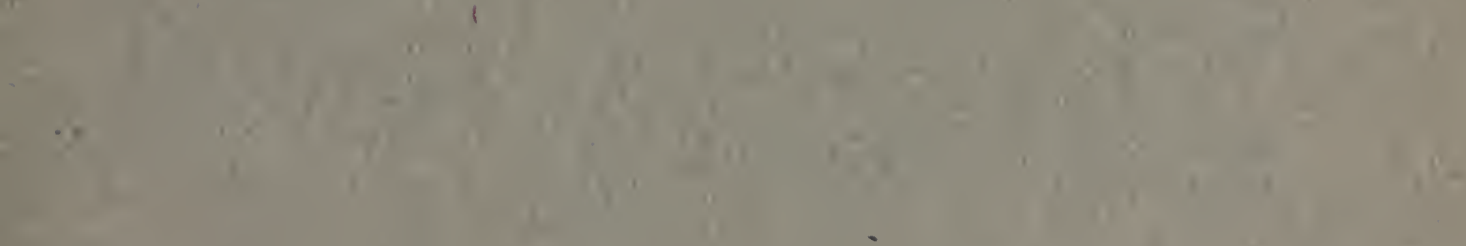

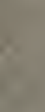

1.
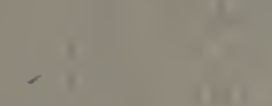

$2=$

-1,

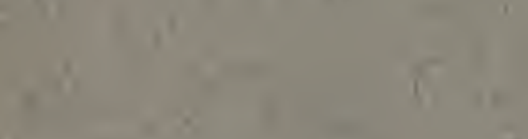
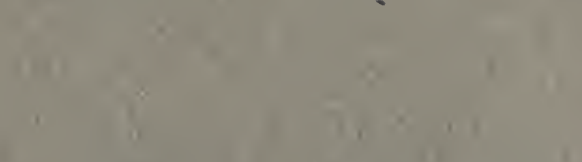

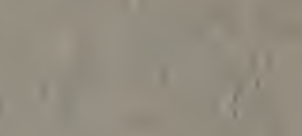

$$
\begin{aligned}
& \text { Sis } \\
& 11= \\
& \text { (1) } \\
& x-1 \\
& 7,15,3,
\end{aligned}
$$

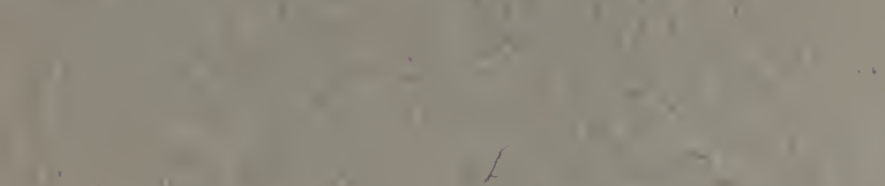

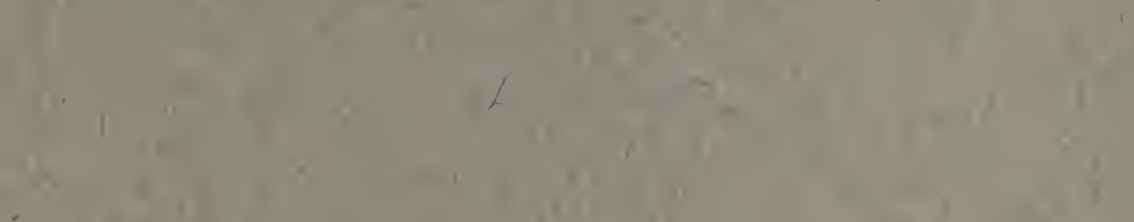

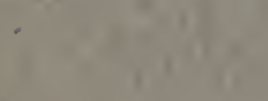

Sis

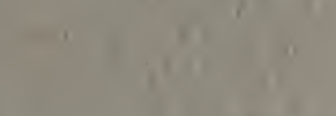

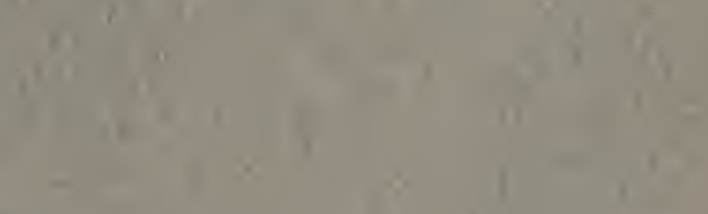

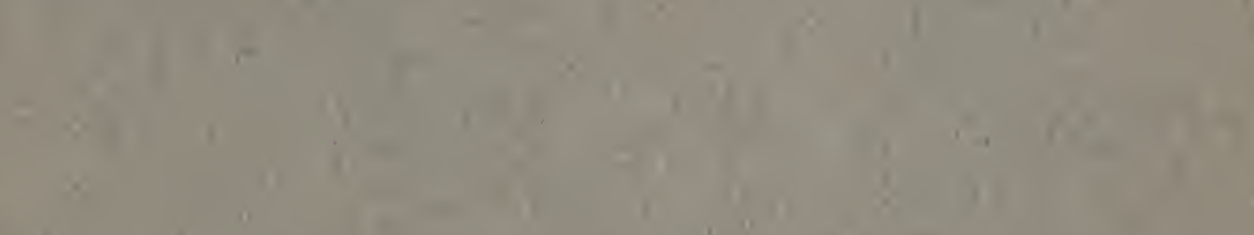

1.

inyl

$$
z+x|x|
$$





$$
\begin{gathered}
365230 \\
5 \\
5-\infty
\end{gathered}
$$

UNIVERSITY OF CALIFORNIA LIBRARY 
